\title{
A Multi-Factor Measure for Cross-Market Liquidity Commonality
}

\author{
Jianxin Wang ${ }^{*}$ \\ Australian School of Business \\ University of New South Wales \\ Sydney Australia \\ Jx.wang@unsw.edu.au
}

January 2011

\begin{abstract}
Liquidity commonality is defined as liquidity co-movements across assets or markets. In the current literature, it is measured relative to a single factor, i.e., the average liquidity across assets or markets. However liquidity co-movements may not be fully captured by this single factor. Other factors, e.g., aggregate return and volatility, may also contribute to liquidity comovements. Using Asian stock markets as an example, this paper reports that following findings: (1) From January 2000 to April 2010, cross-market liquidity commonality accounts over $9 \%$ of daily liquidity variations for Asian emerging markets, and around $14 \%$ for Asian developed markets. These numbers are considerably higher than the $1 \%$ to $2 \%$ reported in previous studies based on cross-asset liquidity commonality. (2) Regional factors affect liquidity commonality through shocks in liquidity and volatility, while global factors affect liquidity commonality through return and volatility. (3) Cross-market liquidity commonality has increased significantly during and after the recent global financial crisis, accounting up to $14 \%$ and $21 \%$ of liquidity variations in Asian emerging and developed market respectively. It is not very sensitive to bull-bear market cycles. The large and rising common liquidity component across regional markets has significant implications for international portfolio flows and risk management.
\end{abstract}

* I thank Anthony Baluga and Pile Quising for their research assistance. Comments and suggestions from Maria Socorro G. Bautista, Joseph Zveglich, and seminar participants at the Asian Development Bank are greatly appreciated. All errors are my own. 


\section{Introduction}

Liquidity is a key measure of market quality and a critical pre-condition for financial market growth and development. It is directly linked to investors' required returns on investments (Amihud and Mendelson, 1986), hence the cost of capital, and a major factor affecting asset pricing efficiency (Chordia, Roll, and Subrahmanyam, 2008). Liquidity plays a central role in hedging and risk management (Das and Hanouna, 2009; Acharya and Schaefer, 2006), and in triggering and propagating financial crises (Borio, 2004), particularly in the most recent episode (Brunnermeier, 2009; Gorton, 2009).

While traditionally liquidity is measured and analysed for individual assets, Chordia, Roll, and Subrahmanyam (2000), Hasbrouck and Seppi (2001), and Huberman and Halka (2001) are the first to show a common liquidity component among stocks in the United States. Chordia, Roll, and Subrahmanyam (2000) call the common component "liquidity commonality". Huberman and Halka (2001) call it "systematic liquidity". This finding has been confirmed in other markets. ${ }^{1}$ Subsequent studies suggest that systematic liquidity is an important determinant of an asset's expected return, e.g. Pastor and Stambaugh (2003), Acharya and Pedersen (2005), and Korajczyk and Sadka (2008). Several studies have offered explanations for cross-asset liquidity commonality, e.g. funding liquidity (Brunnermeier and Pedersen, 2009), mutual fund ownership (Koch, Ruenzi, and Starks, 2009), large market declines (Hameed, Kang, and Viswanathan, 2010), and financial liberalization (Lin, 2010).

Recently Brockman, Chung, and Perignon (2009) and Zhang, Cai, and Cheung (2009) examine cross-market liquidity commonality. Brockman, Chung, and Perignon (2009) document within and cross-market liquidity commonality for 47 developed and emerging stock markets. Zhang, Cai, and Cheung (2009) explore factors explaining within and cross-

\footnotetext{
${ }^{1}$ A partial list includes Hong Kong (Brockman and Chung, 2002), Australia (Fabre and Frino, 2004), United Kingdom (Galariotis and Giouvris, 2007), and Thailand (Pukthuanthong-Le and Visaltanachoti, 2009). Karolyi, Lee, and van Dijk (2009) document within-country commonality in return, liquidity, and turnover in 40 developed and emerging markets.
} 
market liquidity commonality for 25 developed stock markets. As in the case of withinmarket liquidity commonality, cross-market liquidity commonality represents globally nondiversifiable liquidity risk. Given the broad trend in financial market liberalization and integration and the recent global financial crisis, understanding the magnitude, the dynamics and the determinants of this global commonality takes on greater importance.

In the current literature, liquidity commonality is determined by a single factor, the weighted average liquidity across assets, using a model similar to the market model for stock returns. Liquidity commonality is measured by the beta coefficient of the market average liquidity or the regression $\mathrm{R}^{2}$. This approach assumes that liquidity co-movements across different stocks are explained by the changes in the market average liquidity. However, the theoretical model of Copeland and Galai (1983) demonstrates that liquidity is affected by a range of factors such as the price level, return variance, trading activity, and the degree of competition in liquidity supply. Their model demonstrates an inverse relationship between informed trading and liquidity supply, which is further elaborated and extended in subsequent studies; see O'Hara (1995, Chapters 3 and 6). Recent studies cited above indicate that liquidity co-movements are associated with market-wide return, institutional ownership and funding constraints, and market-wide events such as financial liberalization. Both theory and empirical findings lead to the question whether the changes in the market average liquidity fully capture the liquidity effects of these diverse risk factors. If not, there may be other factors affecting liquidity co-movements across assets, and the current approach may underestimate commonality therefore systematic liquidity risk.

This paper compares the current single-factor approach against a multi-factor model for estimating cross-market liquidity commonality among twelve Asian stock markets. Unlike Brockman, Chung, and Perignon (2009) and Zhang, Cai, and Cheung (2009) who examine liquidity commonality among stocks in different markets, I measure liquidity at the 
market level and estimate liquidity co-movements across market within the region. Global portfolio decisions are mostly made at the market level, not at the stock level. Global investors, economic policymakers, and market regulators tend to focus on market-wide characteristics, such as liquidity and volatility, not those of individual stocks. As in the case of multi-factor models for stock returns, there is no theoretical guidance on the choice of common liquidity factors. I use three sets of liquidity factors: one set based on markets in the United Kingdom and the United States representing the global factors, one set based on Asian developed markets, and one set based on Asian emerging markets. The two sets of Asian regional factors are motivated by the diverse economic and financial development within the region. Factors from regional developed markets are expected to have greater external impacts than factors from regional emerging markets. In addition to the cross-market average liquidity, each set of liquidity factors also includes cross-market average return and volatility. Hameed, Kang, and Viswanathan (2010) show a strong positive relation between stock liquidity and returns. Greater volatility increases the risk of supplying liquidity and the required return. Given the aim of modelling daily liquidity dynamics, other factors such as the total market capitalization (Brockman, Chung, and Parignon, 2009) remain relatively stable. The choice of liquidity factors is discussed in detail in section IV.

Several empirical issues are addressed in detail in this study. First, most studies follow Chordia, Roll, and Subrahmanyam (2000) and use the first difference of their liquidity measures. This has been criticised by Hasbrouck and Seppi (2001) for over differencing that leads to autocorrelation in residuals. Chordia, Sarkar, and Subrahmanyam (2005) use liquidity level after removing time trend and seasonality. This paper uses a similar procedure for seasonality adjustments. The augmented Dickey-Fuller test shows no unit root in the adjusted liquidity series. Second, using the modified R/S statistic of Lo (1991), the paper shows that liquidity has long-run dependency, similar to volume and volatility (Bollerslev 
and Jubinski, 1999) and the bid-ask spread (Plerou, Gopikrishnan, and Stanley, 2005). This long-run persistence has not been included in previous studies and is captured in this study by the heterogeneous autoregressive (HAR) model of Corsi (2009). Third, the sample from early 2000 to early 2010 includes major bull-bear market cycles. I use several tests to identify structural breaks and report the weighted average parameters across sub-periods.

In the current study, the liquidity measure used is a modified version of the Amihud (2002) measure, where the absolute return is replaced by daily volatility. The measure for cross-market liquidity commonality is the partial $\mathrm{R}^{2}$ of the common liquidity factors, after controlling local market factors such as lagged liquidity, volatility, and returns. The main empirical findings are the following:

- Factors from Asian developed markets have greater liquidity impact on local markets than factors from Asian emerging markets. The global factors have the smallest impact.

- The regional and global factors affect local market liquidity through different channels. The regional effects come from the (unexpected) liquidity and volatility. Regional returns have little impact on liquidity commonality. The effects of the global markets come mostly from lagged return and volatility

- Over the sample period from January 2000 to April 2010, liquidity commonality explains around $9 \%$ of daily liquidity variations for Asian emerging markets, and around $14 \%$ of daily liquidity variations for Asian developed markets. When measured relative to a single global average liquidity, as in previous studies, liquidity commonality explains only $1.5 \%$ of local market liquidity.

- The time trend of liquidity commonality varies significantly across markets. Some had strong increases in recent years. Others peaked early in the sample period. On average, commonality of Asian emerging markets was relatively flat until 2008-2010, while commonality of Asian developed markets has increased steadily since 2002. The bull- 
bear market cycles do not appear to have a strong effect on liquidity commonality. Commonality increase in Asian emerging markets during the global financial crisis from late 2007 to early 2009. It surged sharply in Asian developed markets and continues to rise during the post-crisis market rebound in 2009 and early 2010.

Overall, cross-market liquidity commonality based on a multi-factor model is much higher than stock-level liquidity commonality reported in Brockman, Chung, and Perignon (2009) and Zhang, Cai, and Cheung (2009). It is also higher than the $\mathrm{R}^{2} \mathrm{~s}$ from the market model for stock liquidity in Chordia, Roll, and Subrahmanyam (2000) and Hameed, Kang, and Viswanathan (2010). While commonality is higher in developed markets, it is not always in line with economic or financial development: Malaysia and Thailand have higher commonality with external markets than more advanced markets such as Korea and Taiwan.

The next section explains the data, liquidity measure, and seasonality adjustments. The long memory in liquidity is tested in Section III, which also presents the HAR model of liquidity. Section IV discusses the liquidity factors, the extension to the HAR-Liq model, measures for liquidity commonality, and tests of parameter stability. The findings on liquidity factors and liquidity commonality for each market are discussed in Section $\mathrm{V}$ for the full sample and in sub-periods. Section VI offers some concluding remarks.

\section{Data and Preliminary Analysis}

I examine twelve stock markets in Asia, including eight emerging markets: China (CH), India (IN), Indonesia (ID), Korea (KO), Malaysia (MA), Philippines (PH), Taiwan (TW), and Thailand (TH), and four regional developed markets: Australia (AU), Japan (JP), Hong Kong (HK), and Singapore (SG). The global markets are represented by the United States (US) and the United Kingdom (UK). Table 1 lists the local indices representing these markets. The sample period is from 1 January 2000 to 30 April 2010. I avoid the Asian financial crisis period in the late 1990s and its related issues. The daily high, low, closing 
prices, and trading volume of each market are taken from Bloomberg ${ }^{2}$. Figure 1 shows that these markets have similar cycles, the down trend in 2000 to 2002, a strong bull run in 2003 to 2007 , the global financial crisis from late 2007 to early 2009 , and the recent rebound. Liquidity commonality will be estimated in the sub-periods and in different market cycles.

\section{A. Liquidity Measure}

Liquidity has many facets. According to Kyle (1985), “[T]hese include 'tightness' (the cost of turning around a position over a short period of time), 'depth' (the size of an order flow innovation required to change prices a given amount), and 'resiliency' (the speed with which prices recover from a random, uninformative shock)." Not surprisingly there is a variety of liquidity measures in the literature. Korajczyk and Sadka (2008) examine the common component of eight liquidity measures. Goyenko, Holden, and Trzcinka (2009) run a horse race of twenty four liquidity measures. This study examines the daily variation of the overall market liquidity, which rules out regression-based liquidity measures that are estimated over a longer period, e.g. Lesmond, Ogden, and Trzcinka (1999) and Pastor and Stambaugh (2003). Trading volume-based measures, e.g. volume and turnover ratio, have been criticised for not reflecting changes in trading costs during high volatility periods, e.g. Lesmond (2005). Transaction cost-based measures, e.g. the quoted and effective bid-ask spreads, require intraday data that are not readily accessible for many markets in the sample.

A widely used liquidity measure is the ratio of absolute return to trading volume proposed by Amihud (2002). Let $r$ be the daily return and $v$ be the daily trading volume, the Amihud measure is $|\mathrm{r}| / \mathrm{v}$. It is a price impact measure, as opposed to a trading cost measure such as the bid-ask spread. It measures illiquidity: for a given volume $\mathrm{v}$, price change $|\mathrm{r}|$ should be small in a deep and liquid market. Korajczyk and Sadka (2008, Table 10) find that the Amihud measure is one of the two liquidity measures (among eight) that are priced in the

\footnotetext{
${ }^{2}$ The volume for the S\&P 500 is taken from DataStream. The volume from Bloomberg is much lower than those of DataStream and Yahoo Finance.
} 
cross-section of stock returns. Hasbrouck (2009, Table 2) shows that it is highly correlated with two measures of liquidity based on microstructure data. ${ }^{3}$

I use a modified version of the Amihud measure: a market's liquidity on a trading day is measured as $L=\ln (1+v / \sigma)$, where $\mathrm{v}$ is the aggregate trading volume and $\sigma$ is the marketwide daily volatility. The motivation is that daily volatility is better than the absolute daily return $|\mathrm{r}|$ in capturing the price variation during a trading day. Volatility is measured as $\ln \left(\mathrm{P}^{\mathrm{H}} / \mathrm{P}^{\mathrm{L}}\right)$ where $\mathrm{P}^{\mathrm{H}}$ and $\mathrm{P}^{\mathrm{L}}$ are the daily high and low prices. Studies, e.g. Alizadeh, Brandt, and Diebold (2002), have shown that the log price range is an efficient estimator of the daily volatility. The logarithmic transformation mitigates the effect of extremely low volatility. The measure is a monotonic transformation of the volume required to increase volatility by one unit. The higher the measure is, the deeper the market is in the sense of Kyle (1985), and the greater liquidity the market has. ${ }^{4}$

A word of caution is required when comparing the Amihud-type liquidity measures across different markets. Because of the substantial differences in share prices and exchange rates, it may take US $\$ 1$ million to buy 100,000 shares in one market, e.g. Singapore, but only US $\$ 10,000$ to buy the same number of shares in another market, say Indonesia. In terms of trading volume, Indonesia may appear to be more active than Singapore, while Singapore may actually have greater trading value. Ideally one would like to measure price impact (therefore liquidity) based on the dollar value traded. However trading value is not available for most markets in the sample. Fortunately the focus is on how liquidity changes over time, not liquidity differences across markets. When liquidity is measured consistently over time, the cross-market price level effect should not significantly affect liquidity dynamics.

\footnotetext{
${ }^{3}$ Recent studies using the Amihud measure as the main liquidity measure include Acharya and Pedersen (2005), Avramov, Chordia, and Goyal (2006), Watanabe and Watanabe (2008), Kamara, Lou, and Sadka (2008), Korajczyk and Sadka (2008), and Hasbrouck (2009), among others.

${ }^{4}$ Karolyi, Lee, and van Dijk (2009) use a similar $\log$ transformation of the Amihud measure: $-\ln \left[1+|\mathrm{r}| /\left(\mathrm{p}^{*} \mathrm{v}\right)\right]$ where $\mathrm{p}$ is the end-of-day price.
} 


\section{B. Summary Statistics}

Table 2 presents the summary statistics of daily return, volatility, and liquidity. Daily returns are calculated as $100 \times \ln \left(\mathrm{P}_{\mathrm{t}} / \mathrm{P}_{\mathrm{t}-1}\right)$, where $\mathrm{P}_{\mathrm{t}}$ is the closing index value on day $\mathrm{t}$. Over the sample period, returns in emerging markets are much higher than returns in developed markets and the UK and the US; are more volatile; and are more negatively skewed. These statistics are consistent with the stylized contrast between emerging and developed markets. Emerging markets all show return persistence, with the first-order autocorrelation $\rho(1)>0$. Such persistence is particularly strong for Indonesia, Malaysia, and the Philippines. While most developed markets show return reversal, i.e. $\rho(1)<0$, the US and the UK have stronger return reversals than Asian developed markets. With a critical value of 11.07, the Ljung-Box Q statistic for five lags shows significant serial correlation for most emerging markets and the US and the UK. While the stationarity of some liquidity measures has been questioned in some studies, e.g. Chordia, Roll, and Subrahmanyam (2000), it is clearly not an issue for daily returns. The augmented Dickey-Fuller test strongly rejects the presence of unit roots. ${ }^{5}$

Trading volume is extremely high in China and Taiwan, where the average daily volumes for the represented indices are 4.3 and 3.2 billion shares respectively. On the other hand, the average daily volume for the SENSEX Index in India is only 40 million shares. On average, trading volumes in Asian emerging markets are much higher than volumes in Asian developed markets. Singapore's average volume is particularly low at 190 million shares per day. Volumes in Asian developed markets have higher skewness and kurtosis, indicating more frequent volume spikes. Volumes in Asian emerging markets tend to be more persistent than volumes in developed markets. The augmented Dickey-Fuller (ADF) test rejects unit roots in volume series.

\footnotetext{
${ }^{5}$ I run the augmented Dickey-Fuller test with a constant and both with and without time trend. Both tests reach the same conclusion. The test statistic with time trend is reported. The critical value at $5 \%$ significance is -3.66 .
} 
The daily volatility measure, calculated as $100 \times \ln \left(\mathrm{P}^{\mathrm{H}} / \mathrm{P}^{\mathrm{L}}\right)$, is on average slightly higher than the volatility estimates from the end-of-day price in the return panel. Highvolume markets do not always have high volatility: India and Korea have low volume but high volatility. Asian emerging markets have the highest volatility on average but the lowest volatility persistence, measured by the first-order autocorrelation and the Ljung-Box Q statistic for five lags. Asian developed markets have higher volatility skewness and kurtosis, indicating more frequent surges in daily volatility. The US and the UK have the highest volatility persistence. There is no unit root in volatility.

The liquidity measure shows a wide disparity of liquidity among emerging markets in Asia. Liquidity in China, Indonesia, Taiwan, and Thailand, is higher than most developed markets. However, liquidity in India, Korea, Malaysia, and the Philippines, is much lower. Asian emerging markets have the highest liquidity skewness and kurtosis, indicating more frequent liquidity spikes. On the other hand, Singapore as a developed market has very low liquidity due to its low trading volume. ${ }^{6}$ The US and the UK have higher average liquidity and lower liquidity skewness and kurtosis than Asian developed and emerging markets. As mentioned before, cross-market liquidity ranking can be very different if trading value were used to measure liquidity. Liquidity persistence is similar across the three groups. ${ }^{7}$

A key issue in measuring liquidity commonality is whether liquidity is stationary and whether the level of liquidity or its first difference should be used. Chordia, Roll, and Subrahmanyam $(2000$, p10) point to the potential problem of non-stationarity in the time series of liquidity levels and opt to use the first difference of their liquidity measures. Hasbrouck and Sappi (2001, p405) suggest that the bid-ask spread and other liquidity measures generally do not have unit roots and argue against over-differencing as it induces

\footnotetext{
${ }^{6}$ Zhang, Cai, and Cheung (2009) reports that Singapore has the second lowest number of trades per stock and the third highest bid-ask spread among six Asian developed markets.

${ }^{7} \operatorname{In}$ comparison to $\ln (1+\mathrm{v} / \sigma), \ln (1+\mathrm{v} /|\mathrm{r}|)$, which is a monotonic transformation of the Amihud (2002) measure, has much higher skewness and kurtosis and much lower persistence.
} 
autocorrelation in computed residuals. In later studies, many have used the first difference, e.g. Zhang, Cai, and Cheung (2009) and Brokeman, Chung, and Perinon, (2009). Some have used liquidity levels adjusted for seasonality, e.g. Chordia, Sarkar, and Subrahmanyam (2005), while others have used both, e.g. Hameed, Kang, and Viswanathan (2010). Most studies do not provide a formal test on the stationarity of their liquidity measures. I address this issue using the ADF test for unit roots. As mentioned, I run the test with and without a time trend. In both cases, it safely rejects the presence of unit roots in the modified Amihud measure for all markets.

\section{Seasonality Adjustments}

Chordia, Sarkar, and Subrahmanyam (2005) demonstrate the presence of strong seasonality in their measures of stock and bond liquidity. For example, liquidity is much higher on Monday and Tuesday and during the summer months of July to September, and much lower surrounding holidays and during crisis periods. After removing the seasonality, they report that the ADF and the Phillips-Perron tests both reject unit roots in their adjusted liquidity measures. Since I do not seek to explain liquidity variations associated with these seasonalities, I follow a similar procedure to remove them, as did Hameed, Kang, and Viswanathan (2010). Let $\mathrm{L}_{\mathrm{i}, \mathrm{t}}=\ln \left(1+\mathrm{v}_{\mathrm{i}, \mathrm{t}} / \sigma_{\mathrm{i}, \mathrm{t}}\right)$ be the liquidity in market $\mathrm{i}$ on day $\mathrm{t}$. I regress $\mathrm{L}_{\mathrm{i}, \mathrm{t}}$ on a set of seasonality variables:

$$
\mathrm{L}_{\mathrm{i}, \mathrm{t}}=\beta_{0}+\beta_{1} \mathrm{t}+\beta_{2} \mathrm{t}^{2}+\sum_{\mathrm{d}=1}^{4} \beta_{3, \mathrm{~d}} \mathrm{DAY}_{\mathrm{t}, \mathrm{d}}+\sum_{\mathrm{m}=1}^{11} \beta_{4, \mathrm{~m}} \mathrm{MONTH}_{\mathrm{t}, \mathrm{m}}+\beta_{5} \text { HOLIDAY }_{\mathrm{t}}+\mathrm{u}_{\mathrm{i}, \mathrm{t}}
$$

where $\mathrm{t}$ and $\mathrm{t}^{2}$ are time trend and its square, $\mathrm{DAY} \mathrm{Y}_{\mathrm{t}, \mathrm{d}}, \mathrm{d}=1, \ldots, 4$, are dummies for Monday to Thursday, $\mathrm{MONTH}_{\mathrm{t}, \mathrm{m}}, \mathrm{m}=1, \ldots, 11$, are dummies for January to November, and HOLIDAY $\mathrm{t}$ is the dummy for the day before and the day after a holiday. The residual $u_{i, t}$ is used to construct the following variance equation:

$$
\log \left(\mathrm{u}_{\mathrm{i}, \mathrm{t}}^{2}\right)=\mathrm{x}_{\mathrm{i}, \mathrm{t}}^{\prime} \gamma_{\mathrm{i}}+\mathrm{v}_{\mathrm{i}, \mathrm{t}}
$$


where $\mathrm{x}_{\mathrm{i}, \mathrm{t}}$ is the same set of variables as in equation (1). The standardized residual is then given by $\hat{\varepsilon}_{\mathrm{i}, \mathrm{t}}=\hat{\mathrm{u}}_{\mathrm{i}, \mathrm{t}} / \exp \left(\mathrm{x}_{\mathrm{i}, \mathrm{t}}^{\prime} \hat{\gamma}_{\mathrm{i}} / 2\right)$. Let $\mathrm{a}_{\mathrm{i}}$ be the mean of $\mathrm{L}_{\mathrm{i}, \mathrm{t}}$ and $\mathrm{b}_{\mathrm{i}}$ be set to $\left[\operatorname{var}\left(\mathrm{L}_{\mathrm{i}, \mathrm{t}}\right) / \operatorname{var}\left(\hat{\varepsilon}_{\mathrm{i}, \mathrm{t}}\right)\right]^{1 / 2}$.

The adjusted liquidity, calculated as $\mathrm{L}_{\mathrm{i}, \mathrm{t}}^{\text {adj }}=\mathrm{a}_{\mathrm{i}}+\mathrm{b}_{\mathrm{i}} \hat{\varepsilon}_{\mathrm{i}, \mathrm{t}}$, has the same mean and variance as the original series $\mathrm{L}_{\mathrm{i}, \mathrm{t}}$. In all subsequent analyses, $\mathrm{I}$ use $\mathrm{L}_{\mathrm{i}, \mathrm{t}}$ to denote the adjusted liquidity to simplify notation. Figure 2 shows a comparison between the original and the adjusted liquidity series for Australia. It seems that the de-trending worked better in the early sample period. There was a surge in liquidity associated with the market rebound after the recent global financial crisis (see Figure 1). Table 3 reports the summary statistics of the adjusted daily liquidity. The mean and standard deviation are the same as the original liquidity series by design. The kurtosis is slightly higher. The first-order autocorrelation and the Ljung-Box Q5 statistic show much lower persistence over time. The ADF statistic shows stronger rejection of null of unit roots.

In addition to daily liquidity, other variables in Table 1 are also filtered through the above procedure to remove any seasonality. While the original volume and volatility are used to construct the daily liquidity measure, they are taken logarithms and then filtered through the above procedure for subsequent analysis. The logarithmic transformation is often used in volatility modelling. Andersen, Bollerslev, and Diebold (2007) show that the log volatility has much lower skewness and kurtosis than volatility itself. Plerou, Gopikrishnan, and Stanley (2005) show that liquidity measures such as the bid-ask spread is a logarithmic function of the number of transactions and the trading volume.

\section{Sample Construction}

To measure liquidity commonality, I need to match daily liquidity measures across markets. Many markets do not have the same trading days. If only the common trading days across 12 markets were used, the sample size would be reduced to 1740 days from over 2500 
days for individual markets. In addition to a substantial reduction in sample size, the missing days are also likely to distort the daily liquidity dynamics.

To overcome this problem, a trading day is removed only if more than half of the markets are not open. For example, if China is trading on a given day, I need to calculate the average liquidity of emerging markets (without China), the average liquidity of Asian developed markets, and the average liquidity of the UK and the US. These averages are calculated when more than half of the markets in the group are trading on the day. This process preserves most trading days even if one or two markets are not trading. The final sample size ranges from a low of 2442 for China to a high of 2540 for Australia.

\section{Long Memory in Liquidity}

Studies, e.g. Bollerslev and Jubinski (1999), have shown that both volume and volatility have long-run dependence, often termed as long memory. The liquidity measure is based on volume and volatility, therefore may also have long memory. If present, long memory should be accounted for when modelling liquidity dynamics. Otherwise the standard "omitted variable bias" applies when the "omitted" long memory is correlated with any of the explanatory variables (Greene, 2008, p133).

\section{A. Testing for Long Memory}

I use the modified R/S (MRS) statistic of Lo (1991) to test the presence of long memory in the daily liquidity series. It is a modification of the classical R/S test of Mandelbrot (1972), which often fails to reject long memory when there is none. Consider a time series $X_{1}, X_{2}, \ldots, X_{T}$. The sample mean, variance, and autocovariance of $j^{\text {th }}$ order are given by $\overline{\mathrm{X}}, \hat{\sigma}_{0}^{2}$, and $\hat{\gamma}_{\mathrm{j}}$ respectively. The modified sample variance, after taking into account of autocovariance, is given by $\widehat{\sigma}^{2}(q) \equiv \hat{\sigma}_{0}^{2}+\sum_{j=1}^{q}\left(1-\frac{j}{q+1}\right) \hat{\gamma}_{j}$ where $q$ is the number of lags with $0<\mathrm{q}<\mathrm{T}$. The modified $\mathrm{R} / \mathrm{S}$ statistic is defined as 


$$
\mathrm{Q}_{\mathrm{T}}(\mathrm{q}) \equiv \frac{1}{\widehat{\sigma}(\mathrm{q})}\left[\max _{1 \leq \mathrm{k} \leq \mathrm{T}} \sum_{\mathrm{j}=1}^{\mathrm{k}}\left(\mathrm{X}_{\mathrm{j}}-\overline{\mathrm{X}}\right)-\min _{1 \leq \mathrm{k} \leq \mathrm{T}} \sum_{\mathrm{j}=1}^{\mathrm{k}}\left(\mathrm{X}_{\mathrm{j}}-\overline{\mathrm{X}}\right)\right] .
$$

The numerator is the range of the running sums of deviations from the sample mean, while the denominator is the modified standard deviation (hence the name $\mathrm{R} / \mathrm{S}$ test). Instead of $\widehat{\sigma}(\mathrm{q})$, the classical R/S statistic uses the sample standard deviation $\hat{\sigma}_{0}^{2}$ in the denominator. Lo (1991) suggests to choose the lag value $\mathrm{q}$ as the integer part of $\left(\frac{3 \mathrm{~T}}{2}\right)^{1 / 3}\left(\frac{2 \widehat{\rho}}{1-\widehat{\rho}^{2}}\right)^{2 / 3}$ with $\hat{\rho}$ being the first-order autocorrelation coefficient of X. Lo (1991) derives the asymptotic distribution of $\operatorname{MRS}(\mathrm{q})=\mathrm{Q}_{\mathrm{T}}(\mathrm{q}) / \sqrt{\mathrm{T}}$. For a one-sided test of the null hypothesis of no long memory, the null is rejected when $\operatorname{MRS}(q)>1.862$.

The last column of Table 2 reports the estimated MRS for the liquidity series. The number of lags q is selected base on Lo's suggestion. For all markets, the null hypothesis of no long memory in liquidity is strongly rejected. In fact, the MRSs of liquidity are much higher than those of volatility (not reported here). India has an exceptionally high MRS, which leads to a high average value for Asian emerging markets. The median MRS of Asian emerging markets is very similar to that of Asian developed markets. The US and the UK have the lowest MRS. The results of the modified R/S test are consistent with the autocorrelation functions depicted in Panels A and B of Figure 3. For both emerging markets (Panel A) and developed markets (Panel B), the decay in autocorrelation is very slow. The correlations between today's liquidity and that of 100 days ago are statistically significant and above 0.1 for nine of the twelve markets. India has a correlation of 0.34 and Japan and the UK have a correlation of 0.22 after 100 days.

\section{B. Modelling Long Memory}

Given the strong evidence of long memory, a model is required to capture its effect on daily liquidity variations. In the volatility literature, long memory is traditionally captured by fractionally integrated models, e.g. Andersen, Bollerslev, Diebold and Labys (2003). Corsi 
$(2009)^{8}$ proposes a heterogeneous autoregressive model for realized volatility (HAR-RV) based on the "heterogeneous market hypothesis" of Müller, et al. (1997). The HAR-RV model provides a simple way to capture volatility long memory and has been widely adopted in recent studies. ${ }^{9}$ In this paper, the heterogeneous autoregressive model is adopted to capture long memory in liquidity and is labelled as the HAR-Liq model.

As in the basic HAR-RV model, the HAR-Liq model includes past liquidity aggregated over different time horizons as explanatory variables. The average liquidity in the past $\mathrm{h}$ days is $\mathrm{L}_{\mathrm{i}, \mathrm{t}-1}^{\mathrm{k}}=\frac{1}{\mathrm{~h}} \sum_{\mathrm{s}=\mathrm{t}-\mathrm{h}}^{\mathrm{t}-1} \mathrm{~L}_{\mathrm{i}, \mathrm{s}}$, with $\mathrm{k}=\mathrm{D}$ (day), $\mathrm{W}$ (week), $\mathrm{M}$ (month), and $\mathrm{Q}$ (quarter) for $\mathrm{h}=1,5,22$, and 66 respectively. The HAR-Liq model is given by

$$
\mathrm{L}_{\mathrm{i}, \mathrm{t}}=\beta_{0}+\sum_{\mathrm{k}=\mathrm{D}}^{\mathrm{Q}} \beta_{\mathrm{k}} \mathrm{L}_{\mathrm{i}, \mathrm{t}-1}^{\mathrm{k}}+\varepsilon_{\mathrm{i}, \mathrm{t}}
$$

Table 4 reports the estimation of equation (4) for individual markets. Bold numbers are statistically significant at the 5\% level. Most of the lagged daily, weekly, and monthly liquidity are highly significant. For unknown reasons, the lagged weekly liquidity has the strongest impact on today's liquidity. This has been found in volatility studies of equities and bonds (Andersen, Bollerslev, and Diebold, 2007) and exchange rates (Wang and Yang, 2009). Since the lagged quarterly liquidity is significant only for three of the twelve markets, it is not included in the subsequent analysis. With lagged daily, weekly, and monthly liquidity, most of the long-run dependency is removed. Panel $\mathrm{C}$ of Figure 3 presents the autocorrelation function of the HAR-Liq residuals. The residual autocorrelations are very close to zero for China, India, and Japan. The same holds true for all the other markets. By mixing of a small number of lagged liquidity with different aggregation frequencies, the HAR-Liq model produces a good approximation to long-run dependencies in liquidity.

\footnotetext{
${ }^{8}$ The working paper was circulated in 2003.

${ }^{9}$ Recent studies using the HAR-RV model includes Andersen, Bollerslev, and Diebold (2007), Andersen, Bollerslev, and Huang (2006), Bollerslev, Kretschmer, Pigorsch and Tauchen (2009), Corsi, Kretschmer, Mittnik, and Pigorsch (2005), Forsberg and Ghysels (2006), and Maheu and McCurdy (2010).
} 


\section{Model Specification}

In this section, I extend the baseline HAR-Liq model to include additional local, regional, and global factors. The aim is to estimate the percentage variation of the individual market liquidity explained by a common set of regional and global factors, i.e. to measure cross-market liquidity commonality. A proper measure can only be achieved when the impact of local liquidity factors are included.

\section{A. Liquidity Factors}

There are several well-known liquidity determinants in the literature, especially for equities. These include stock return and volatility, firm size and index inclusion, insider holdings and ownership concentration, market sentiment and noise trading, information risk such as the probability of informed trading and order imbalance, etc. This study focuses on the overall market liquidity and its daily variations, which limits the choice of liquidity factors. Market size and ownership structure are relatively stable on a day-to-day basis. Information risk measures are individual stock-based and require intraday data, which are not available for many markets. Market sentiment and noise trading are not directly observable and often approximated by other market variables.

This leaves the market return and volatility as the key liquidity determinants. Market return has a direct impact on investor confidence and sentiment, and on investors' ability to obtain funding to supply liquidity, e.g. Brunnermeier and Pedersen (2005). Hameed, Kang, and, Viswanathan (2010) present strong evidence of a causal effect from stock return to liquidity. Volatility reflects risks from various sources, e.g. asset fundamentals, information precision, noise trading, etc. High risks increase the cost of and the required return for supplying liquidity. It is well documented that higher volatility leads to higher bid-ask spread and lower liquidity, e.g. Wang (1999) and Wang and Yau (2000). 
Several studies have documented liquidity commonality as a determinant of individual asset liquidity. Chordia, Roll, and Subrahmanyam (2000) were the first to show a significant contemporaneous co-movement between the market average liquidity and individual stock liquidity in the US. The relationship is similar to the CAPM model for stock returns and the co-movement is termed "liquidity commonality". Recently Brokeman, Chung, and Perinon (2009), Karolyi, Lee, and van Dijk (2009), and Zhang, Cai, and Cheung (2009) all provide evidence of liquidity commonality in international settings. Motivated by these findings, the average regional or global liquidity measures are included as co-determinant factors for individual market liquidity.

\section{B. Extensions to the HAR-Liq Model}

Given the liquidity factors identified above, I now specify the empirical model used to measure liquidity commonality. The starting point is the baseline HAR-Liq model in equation (4). In addition to lagged local liquidities, local return and volatility are important factors as discussed above. The regional and global factors include return, volatility, and liquidity. The global factors are calculated as the average values of the UK and the US. The regional factors are calculated as the average values across Asian markets, excluding the market being analysed.

Since markets in London and New York open after most Asian markets are $\operatorname{closed}^{10}$, there is little contemporaneous effect from these markets to Asia. Therefore only lagged global factors are added to the HAR-Liq model. The lagged values for global liquidity, volatility, and return, are calculated in the same way as the lagged liquidity in equation (4). Only lagged daily and weekly liquidity $\left(\mathrm{L}_{\mathrm{G}, \mathrm{t}-1}^{\mathrm{D}}\right.$ and $\left.\mathrm{L}_{\mathrm{G}, \mathrm{t}-1}^{\mathrm{W}}\right)$, volatility $\left(\sigma_{\mathrm{G}, \mathrm{t}-1}^{\mathrm{D}}\right.$ and $\left.\sigma_{\mathrm{G}, \mathrm{t}-1}^{\mathrm{W}}\right)$, and return $\left(\mathrm{r}_{\mathrm{G}, \mathrm{t}-1}^{\mathrm{D}}\right.$ and $\left.\mathrm{r}_{\mathrm{G}, \mathrm{t}-1}^{\mathrm{W}}\right)$ are included.

\footnotetext{
${ }^{10}$ There is a one-and-half hour overlapping trading period between New Delhi and London. Other Asian markets do not have overlapping trading hours with London and New York.
} 
Given the diversity in economic and financial market development within the region, e.g. Japan versus Indonesia, Asian markets are split into Asian emerging markets and Asian developed markets. Therefore I use two sets of regional factors: one from Asian developed markets and another from Asian emerging markets. Each set includes the average liquidity, volatility, and return, excluding the market being analysed. The challenge is to find a parsimonious way to examine contemporaneous and lagged effects of local, sub-regional, and global factors. For liquidity and volatility, I decompose the contemporaneous values into the expected and unexpected components using the structure of the heterogeneous autoregressive model in equation (4). Let $\mathrm{X}_{\mathrm{j}, \mathrm{t}-1}=\left\{\mathrm{L}_{\mathrm{j}, \mathrm{t}-1}^{\mathrm{D}}, \mathrm{L}_{\mathrm{j}, \mathrm{t}-1}^{\mathrm{W}}, \mathrm{L}_{\mathrm{j}, \mathrm{t}-1}^{\mathrm{M}}, \sigma_{\mathrm{j}, \mathrm{t}-1}^{\mathrm{D}}, \sigma_{\mathrm{j}, \mathrm{t}-1}^{\mathrm{W}}, \sigma_{\mathrm{j}, \mathrm{t}-1}^{\mathrm{M}}, \mathrm{r}_{\mathrm{j}, \mathrm{t}-1}^{\mathrm{D}}, \mathrm{r}_{\mathrm{j}, \mathrm{t}-1}^{\mathrm{W}}, \mathrm{r}_{\mathrm{j}, \mathrm{t}-1}^{\mathrm{M}}\right\}$, where $\mathrm{j}=$ "AD" for Asian developed markets and "AE" for Asian emerging markets. The following regression is estimated via OLS: $Y_{j, t}=\beta_{0}+\beta_{1} X_{j, t-1}+\eta_{j, t}$, with $Y_{j, t}$ being either $L_{j, t}$ or $\sigma_{\mathrm{j}, \mathrm{t}}$. The expected component is $\mathrm{Y}_{\mathrm{j}, \mathrm{t}}^{\mathrm{E}}=\widehat{\beta}_{0}+\widehat{\beta}_{1} \mathrm{X}_{\mathrm{j}, \mathrm{t}-1}$ and the unexpected component is $\mathrm{Y}_{\mathrm{j}, \mathrm{t}}^{\mathrm{U}}=$ $\hat{\eta}_{i, t}{ }^{11}$ The decomposition is motivated by the market efficiency argument that it is the unexpected component that carries new information on the economic and market conditions. The expected component captures the long-run low-frequency variations in liquidity and volatility. The effects from the lagged variables of different time aggregations are reflected in the expected component, resulting in a more parsimonious model. Returns are generally regarded as unpredictable. The contemporaneous and lagged daily returns, $r_{j, t}$ and $r_{j, t-1}^{D}$, are included as explanatory variables for individual market liquidity.

The baseline HAR-Liq model in equation (4) includes the lagged local market liquidities as explanatory variables. The contemporaneous volatility of market $\mathrm{i}$ is decomposed into its expected and unexpected components using the same procedure outlined above, with the subscript $\mathrm{j}$ replaced by the market indicator $\mathrm{i}$. The contemporaneous and

\footnotetext{
${ }^{11}$ Pástor and Stambaugh (2003), Acharya and Pedersen (2005), and Korajczyk and Sadka (2008) use some versions of the autoregressive process to estimate the unexpected component of their liquidity measures.
} 
lagged daily market returns are also included. The final model, incorporating local, regional, and global liquidity factors, is given by

$$
\begin{aligned}
\mathrm{L}_{\mathrm{i}, \mathrm{t}} & =\beta_{0}+\beta_{1} \mathrm{~L}_{\mathrm{i}, \mathrm{t}-1}^{\mathrm{D}}+\beta_{2} \mathrm{~L}_{\mathrm{i}, \mathrm{t}-1}^{\mathrm{W}}+\beta_{3} \mathrm{~L}_{\mathrm{i}, \mathrm{t}-1}^{\mathrm{M}}+\beta_{4} \sigma_{\mathrm{i}, \mathrm{t}}^{\mathrm{E}}+\beta_{5} \sigma_{\mathrm{i}, \mathrm{t}}^{\mathrm{U}}+\beta_{6} \mathrm{r}_{\mathrm{i}, \mathrm{t}}+\beta_{7} \mathrm{r}_{\mathrm{i}, \mathrm{t}-1}^{\mathrm{D}} \\
+ & \beta_{8} \mathrm{~L}_{\mathrm{G}, \mathrm{t}-1}^{\mathrm{D}}+\beta_{9} \mathrm{~L}_{\mathrm{G}, \mathrm{t}-1}^{\mathrm{W}}+\beta_{10} \sigma_{\mathrm{G}, \mathrm{t}-1}^{\mathrm{D}}+\beta_{11} \sigma_{\mathrm{G}, \mathrm{t}-1}^{\mathrm{W}}+\beta_{12} \mathrm{r}_{\mathrm{G}, \mathrm{t}-1}^{\mathrm{D}}+\beta_{13} \mathrm{r}_{\mathrm{G}, \mathrm{t}-1}^{\mathrm{W}} \\
& +\beta_{14} \mathrm{~L}_{\mathrm{AD}, \mathrm{t}}^{\mathrm{E}}+\beta_{15} \mathrm{~L}_{\mathrm{AD}, \mathrm{t}}^{\mathrm{U}}+\beta_{16} \sigma_{\mathrm{AD}, \mathrm{t}}^{\mathrm{E}}+\beta_{17} \sigma_{\mathrm{AD}, \mathrm{t}}^{\mathrm{U}}+\beta_{18} \mathrm{r}_{\mathrm{AD}, \mathrm{t}}+\beta_{19} \mathrm{r}_{\mathrm{AD}, \mathrm{t}-1}^{\mathrm{D}} \\
+ & \beta_{20} \mathrm{~L}_{\mathrm{AE}, \mathrm{t}}^{\mathrm{E}}+\beta_{21} \mathrm{~L}_{\mathrm{AE}, \mathrm{t}}^{\mathrm{U}}+\beta_{22} \sigma_{\mathrm{AE}, \mathrm{t}}^{\mathrm{E}}+\beta_{23} \sigma_{\mathrm{AE}, \mathrm{t}}^{\mathrm{U}}+\beta_{24} \mathrm{r}_{\mathrm{AE}, \mathrm{t}}+\beta_{25} \mathrm{r}_{\mathrm{AE}, \mathrm{t}-1}^{\mathrm{D}}+\varepsilon_{\mathrm{i}, \mathrm{t}}
\end{aligned}
$$

\section{Measures for Liquidity Commonality}

Most studies of liquidity commonality across individual stocks use the "market model" of Chordia, Roll, and Subrahmanyam (2000) to measure liquidity commonality: the first difference of a stock's liquidity measure, e.g. the average bid-ask spread, is regressed against a market liquidity factor calculated as the first difference of the average liquidity across all remaining stocks. Commonality is measured either as the coefficient of the market liquidity factor or the $\mathrm{R}^{2}$ of the regression. Zhang, Cai, and Cheung (2009) explain the size of the estimated coefficient in terms of stock characteristics, e.g. size, international cross-listing, etc. Koch, Ruenzi, and Starks (2009) show that stocks with high mutual fund ownership have greater liquidity co-movement with each other. Hameed, Kang, and Viswanathan (2010) show that the monthly estimated $\mathrm{R}^{2}$ is higher when stock market declines.

In this study, commonality is defined as liquidity variations associated with a set of common factors, and is measured by the partial $\mathrm{R}^{2}$ of the common factors. In addition to the market-wide average liquidity, a stock's liquidity may co-vary with other common factors such as market-wide return and volatility. There is no theoretical reason for the market average liquidity to be the only, or even the main common factor affecting individual stock liquidity. As shown by Koch, Ruenzi, and Starks (2009), adding additional common factors, e.g. a portfolio of stocks with high mutual fund ownership, increases the estimated liquidity co-movements. The same logic applies to estimating cross-market liquidity commonality. In 
this case, the common factors come from regional market averages and the global markets represented by the UK and the US. As mentioned before, if relevant factors are "omitted", the estimated coefficient of the included factor may be biased, and cross-market liquidity comovements may be under-estimated.

Statistically the regression coefficients and the regression $\mathrm{R}^{2}$ capture different aspect of the explanatory variables. The coefficients are scaled covariances between the dependent variable and the explanatory variables, and are evaluated using an arbitrary statistical significance level. By definition, the $\mathrm{R}^{2}$ measures the proportion of the variation in the dependent variable explained by the explanatory variables. Although they are positively correlated, a high $\mathrm{R}^{2}$ does not necessarily imply a large and significant coefficient, and vice versa. In this study, commonality is measured by the partial $\mathrm{R}^{2}$ of the common factors. It is important to control the impact of the local factors. Given the strong correlations between the local and common factors, the $\mathrm{R}^{2}$ of the common factors tend to be inflated when the local factors are excluded.

\section{Testing for Parameter Stability}

While our sample sizes are over 2400, large enough for a model with 25 explanatory variables, the issue of parameter stability becomes more acute as the number of parameters increases. As shown by Figure 1, the sample period covers several large market cycles, which suggests a high likelihood of parameter changes over the sample period. Ignoring the structural changes in a model leads to biased estimates of the true parameters.

The parameter stability of equation (5) is examined using structural break tests discussed by Hansen (1997). These include the Quandt or supF test and the expF and aveF tests proposed by Andrews and Ploberger (1994). I here give a brief discussion of the supF

test. Details of the expF and aveF tests can be found in Andrews and Ploberger (1994) and Hansen (1997). Let $\tau$ be a potential structural break date, from which onward the parameters 
in model (5) may change. The parameters of the unrestricted model in the sub-sample [1, $\tau-1]$ are allowed to be different from those in the sub-sample $[\tau, \mathrm{T}]$, where $\mathrm{T}$ is the full-sample size. On the other hand, the parameters of the restricted model are kept the same in the two sub-samples. The F statistic is calculated as $\mathrm{F}(\tau)=\mathrm{T}\left(\mathrm{SSR}_{\mathrm{R}}-\mathrm{SSR}_{\mathrm{U}}\right) / \mathrm{SSR}_{\mathrm{U}}$, where $\mathrm{SSR}_{\mathrm{R}}$ and $\mathrm{SSR}_{\mathrm{U}}$ are the sums of squared residuals for the restricted model and the unrestricted model respectively. It is calculated for every date between $\pi_{0} \mathrm{~T}$ and $\left(1-\pi_{0}\right) \mathrm{T}$. The trim parameter $\pi_{0}$ $\in(0,1)$ is the fraction of sample trimmed at each end of the sample. It is often set to $15 \%$, which is used here ${ }^{12}$. The first $\pi_{0} \mathrm{~T}$ sample points are used to estimate the initial parameters. The supF statistic is given by $\sup F=\max \{\mathrm{F}(\tau)\}$ for $\pi_{0} \mathrm{~T}<\tau<\left(1-\pi_{0}\right) \mathrm{T}$. The null of no change is rejected if supF is too large, in which case the $\hat{\tau}$ that maximizes $F(\tau)$ is the estimated date of a structural break. A break date is selected if two of the three p-values are smaller than 5\%. ${ }^{13}$ After a structural break is found, the procedure is repeated for the sub-periods. It is stoped when either the length of the sub-period is shorter than $\pi_{0} \mathrm{~T}$ or no new break is found.

Table 5 reports the structural break dates for the twelve markets. Structural breaks are more often in emerging markets than they are in developed markets. China has the most frequent breaks at seven, while Singapore has only one break. Not surprisingly the global financial crisis in 2008-09 is associated with frequent structural breaks. Emerging markets also had frequent breaks in 2001. The distribution of structural breaks over time is roughly consistent with major market cycles depicted in Figure 1. I do not explore the events led to the structural breaks in each market. The aim of the structural break analysis is to ensure the statistical integrity of the parameters estimated, which is critical in assessing the ability of the liquidity factors in explaining local liquidity variations.

\footnotetext{
${ }^{12}$ For China, the first break point is found at the first date after $0.15 \mathrm{~T}$. When $\pi_{0}$ is set to 0.1 , the first break moves to a date before $0.15 \mathrm{~T}$. So $\pi_{0}$ is set to 0.1 for China only for identifying the first break point.

${ }^{13}$ The tests are carried out using the Gauss program provided by Hansen, which is gratefully acknowledged.
} 


\section{Empirical Findings}

Based on the structural break dates in Table 5, the coefficients of equation (5) are estimated for each market and each sub-period. The weighted average coefficients and tstatistics are then calculated, where the weight is the length of the sub-period relative to the full sample size. In this section, the findings on liquidity factors and liquidity commonality are presented and discussed.

\section{A. Significance of Local and Global Liquidity Factors}

Table 6 reports the weighted average coefficients and t-statistics for local and global factors across structural break sub-periods. Again bold numbers are statistically significant at $5 \%$ level. The coefficients of the lagged local liquidities are slightly small than those in Table 3 but remain highly significant. Again the lagged weekly liquidity has the biggest impact on today's liquidity. The unexpected local volatility has a strong negative impact on liquidity in all markets. Although trading volume generally rises with volatility, Table 6 shows that their ratio $\mathrm{v} / \sigma$, hence the liquidity measure $\ln (1+\mathrm{v} / \sigma)$, declines as the unexpected volatility rises. This is consistent with Levy-Yeyati, Schmukler, and Horen (2008) who find a rising Amihud measure $\mid \mathrm{r} / \mathrm{v}$ during volatile markets. The impact of the expected volatility is mixed, positive in emerging markets (ID, $\mathrm{PH}$, and TW) and negative in developed markets (AU and JP). Both the contemporaneous and the lagged returns have significant positive effects on liquidity, with the lagged returns having greater impact in most markets. Hameed, Kang, and, Viswanathan (2010) focus on the lagged return and find the same effect.

The weighted average coefficients of the lagged global factors, represented by the UK and the US, are not significant for most Asian emerging markets except Taiwan. Among Asian developed markets, the lagged global factors are statistically significant for Hong Kong. The one-day lagged global volatility is significant for four markets, but the sign of the coefficients is opposite to that of the unexpected local volatility. After controlling the 
unexpected local volatility, the one-day lagged global volatility increases local market liquidity in Taiwan, Hong Kong, Japan, and Singapore. As discussed below in Table 7, the same positive liquidity impact holds for other external volatilities, e.g. the unexpected volatility in Asian developed and Asian emerging markets. This pattern appears to be puzzling at the first look. However, cross-market volatility spill-over is well documented, e.g. Hamao, Masulis, and $\mathrm{Ng}$ (1990) and $\mathrm{Ng}$ (2000). There is a strong positive contemporaneous correlation between volume and volatility, e.g. Jones, Kaul, Lipson (1994) and Andersen (1996). Therefore external volatility increases both local volatility and trading volume. Once the negative effect of local volatility is accounted for, external volatility increases local liquidity by increasing trading volume.

Table 7 presents the weighted coefficients and t-statistics for factors from Asian developed markets and Asian emerging markets across structural break sub-periods. There are four features in this table. First, there is little impact on individual market liquidity from the expected regional liquidities and none from the expected regional volatilities. Second, while the global return is significant for four of the twelve markets, regional returns have little contemporaneous or lagged effects on individual market liquidity. Third, the link between these regional markets and individual market liquidity mostly comes from the unexpected liquidity and volatility. There is strong positive spill-over from the unexpected regional liquidity. Holding local volatility constant, the unexpected regional volatility enhances local market liquidity. The mechanism is the same as the positive impact from the lagged global volatility discussed above. Fourth, in almost all cases, factors from Asian developed markets have stronger links with individual market liquidity than factors from Asian emerging markets. Therefore using combined regional factors would have underestimated the liquidity impacts of Asian developed markets. 


\section{B. Common Liquidity Factors and Cross-Market Liquidity Commonality}

The overall contributions of common liquidity factors and the cross-market liquidity commonality are reported in Table $8 . \mathrm{PR}_{\mathrm{G}}^{2}, \mathrm{PR}_{\mathrm{AD}}^{2}$, and $\mathrm{PR}_{\mathrm{AE}}^{2}$ are the weighted average partial $\mathrm{R}^{2} \mathrm{~s}$ of factors representing the global markets, Asian developed markets, and Asian emerging markets respectively. As discussed before, these partial $\mathrm{R}^{2} \mathrm{~s}$ do not directly reflect the statistical significance of the corresponding factors reported in Tables 6 and 7. For example, the global factors are not statistically significant at 5\% level for liquidities in China and Korea, while four of the six factors are significant for Taiwan. However, the global factors collectively explain a greater portion of liquidity variations in China and Korea than they do for Taiwan. Table 8 shows that on average, $\mathrm{PR}_{\mathrm{AD}}^{2}>\mathrm{PR}_{\mathrm{AE}}^{2}>\mathrm{PR}_{\mathrm{G}}^{2}$ : Factors from Asian developed markets have greater explanatory power for local market liquidity than factors from Asian emerging markets. The global factors have the lowest explanatory power for local market liquidity. The average values of $\mathrm{PR}_{\mathrm{G}}^{2}, \mathrm{PR}_{\mathrm{AD}}^{2}$, and $\mathrm{PR}_{\mathrm{AE}}^{2}$ are greater for Asian developed markets than they are for Asian emerging markets, indicating Asian developed markets are more sensitive to external liquidity factors than Asian emerging markets.

The column labelled $\mathrm{PR}_{\mathrm{CA}}^{2}$ in Table 8 reports the partial $\mathrm{R}^{2}$ for contemporaneous factors from Asian markets, including $\mathrm{L}_{\mathrm{AD}, \mathrm{t}}^{\mathrm{U}}, \sigma_{\mathrm{AD}, \mathrm{t}}^{\mathrm{U}}, \mathrm{r}_{\mathrm{AD}, \mathrm{t}}, \mathrm{L}_{\mathrm{AE}, \mathrm{t}}^{\mathrm{U}}, \sigma_{\mathrm{AE}, \mathrm{t}}^{\mathrm{U}}$, and $\mathrm{r}_{\mathrm{AE}, \mathrm{t}}$. Recall from Section IV(B) that the expected values of the external factors on day $\mathrm{t}$ are determined by lagged factors. The unexpected components and the contemporaneous return carry new information on market and economic conditions. Here $\mathrm{PR}_{\mathrm{CA}}^{2}$ is used to gauge whether liquidity commonality reflects a common reaction to new information, or whether it is driven by lagged information and momentum. New information plays an important role in liquidity commonality for Malaysia and Indonesia. On the other hand, liquidity commonality in China, Philippines, and Thailand is mainly driven by lagged factors. Among Asian developed 
markets, Singapore and Hong Kong have a much higher information component than Australia and Japan.

The cross-market liquidity commonality is defined as the liquidity variations associated with a common set of factors. Therefore it is measured by the partial $\mathrm{R}^{2}$ of all common factors, $\mathrm{PR}_{\mathrm{CF}}^{2}$ in Table $8^{14}$. The Philippines has the lowest liquidity commonality with external markets. It is somewhat surprising that Korea and Taiwan, the relatively more advanced markets in the group, have below-average liquidity commonality. Taiwan has low exposure to the global factors $\left(\mathrm{PR}_{\mathrm{G}}^{2}\right)$ while Korea has low exposure to the regional factors $\left(\mathrm{PR}_{\mathrm{AD}}^{2}\right.$ and $\left.\mathrm{PR}_{\mathrm{AE}}^{2}\right)$. Thailand and Malaysia have the highest liquidity commonality in the group. While one can speculate the reasons behind the relative rankings, more systematic analyses should be undertaken in future research to explain the cross-market variations. The level of liquidity commonality is more homogeneous among Asian developed markets. Singapore has a low exposure to the global factors and the highest exposure to factors from other Asian developed markets. On average, liquidity commonality accounts for $9.4 \%$ of liquidity variations in Asian emerging markets and 13.7\% in Asian developed markets. The regression $\mathrm{R}^{2}$ shows that equation (5) captures most of the daily variations in individual market liquidity, with $\mathrm{R}^{2}$ ranging from a low of $61 \%$ for Philippines to a high of $85 \%$ for China and Thailand. The model works equally well for both developed and emerging markets, with an average $\mathrm{R}^{2}$ of $75 \%$. Liquidity commonality accounts for a significant portion of the explained liquidity variations in each market. The ratio $\mathrm{PR}_{\mathrm{CF}}^{2} / \mathrm{R}^{2}$ varies from $10 \%$ for Korea and Philippines to $21 \%$ for Singapore and $22.6 \%$ for Hong Kong.

To facilitate comparisons with Brockman, Chung, and Perignon (2009) and Zhang, Cai, and Cheung (2009), Table 8 also reports the weighted average adjusted partial $\mathrm{R}^{2}$ for the common factors $\left(\overline{\mathrm{PR}}_{\mathrm{CF}}^{2}\right)$. In their equation (3), Brockman, Chung, and Perignon (2009)

\footnotetext{
${ }^{14}$ Note that the common factors are not orthogonalized; therefore the sum of partial $\mathrm{R}^{2}$ of individual factors is not the same as the partial $\mathrm{R}^{2}$ of all common factors.
} 
examine the impact of the global average liquidity and average return on the average local market liquidity. They report an average adjusted $\mathrm{R}^{2}$ between $3.8 \%$ and $5.6 \%$, slightly lower than the average $\overline{\mathrm{PR}}_{\mathrm{CF}}^{2}$ in Table $8,5.8 \%$ for Asian emerging markets and $11.1 \%$ for Asian developed markets. However, the contemporaneous local market volatility is also included in their equation (3) hence the calculation of the adjust $\mathrm{R}^{2}$. Given the strong impact from the contemporaneous local market volatility as reported in Table 6 , their adjusted $\mathrm{R}^{2} \mathrm{~s}$ are likely to be boosted by this variable and overstate the true explanatory power of global average liquidity and return. In Zhang, Cai, and Cheung (2009), cross-border liquidity commonality is measured relative to a selected neighbouring market. For example, Japan is used as the neighbouring market for Australia and Korea, Singapore is used as the neighbouring market for Hong Kong, etc. They regress the change in firm liquidity on the changes in the average local liquidity and the average neighbouring liquidity. They find that for the six Asian markets in their sample, the adjusted $\mathrm{R}^{2}$ ranges from $0.2 \%$ for Singapore and $0.8 \%$ for Australia, to $16.3 \%$ for Korea and $17.6 \%$ for Japan. Singapore has the only significant liquidity beta for the neighbouring market, but the beta is negative. Clearly the explanatory power for Japan and Korea mainly comes from the average local liquidity. Compared to these studies, the global and regional factors used in this study provide greater explanatory power as measured by $\overline{\mathrm{PR}}_{\mathrm{CF}}^{2}$.

There are many potential reasons for the difference in the adjusted $\mathrm{R}^{2}$. Brockman, Chung, and Perignon (2009) use the firm-level bid-ask spread and depth. Zhang, Cai, and Cheung (2009) use the firm-level bid-ask spread. Both take the first difference of their daily liquidity measures and estimate the "market model" for liquidity as proposed by Chordia, Roll, and Subrahmanyam (2000). A key contribution of this study is to use other common factors, in addition to the market average liquidity, to measure liquidity commonality. To contrast the popular single factor model with equation (5) while isolating the effect from 
other model choices, I measure liquidity commonality using a single factor which is the global and regional average liquidity:

$$
\mathrm{L}_{\mathrm{i}, \mathrm{t}}=\beta_{0}+\beta_{1} \mathrm{~L}_{\mathrm{i}, \mathrm{t}-1}^{\mathrm{D}}+\beta_{2} \mathrm{~L}_{\mathrm{i}, \mathrm{t}-1}^{\mathrm{W}}+\beta_{3} \mathrm{~L}_{\mathrm{i}, \mathrm{t}-1}^{\mathrm{M}}+\beta_{4} \sigma_{\mathrm{i}, \mathrm{t}}^{\mathrm{E}}+\beta_{5} \sigma_{\mathrm{i}, \mathrm{t}}^{\mathrm{U}}+\beta_{6} \mathrm{r}_{\mathrm{i}, \mathrm{t}}+\beta_{7} \mathrm{r}_{\mathrm{i}, \mathrm{t}-1}^{\mathrm{D}}+\beta_{8} \mathrm{~L}_{\mathrm{SF}, \mathrm{t}}+\varepsilon_{\mathrm{i}, \mathrm{t}}
$$

The first seven explanatory variables are the same local factors as in equation (5). The last variable $\mathrm{L}_{\mathrm{SF}, \mathrm{t}}$ is the single factor calculated as the average liquidity across all other markets, including the UK and the US, on day t. Equation (6) is tested for structural breaks and is estimated for each sub-period as before. The weighted averages of the adjusted partial $\mathrm{R}^{2}$, $\overline{\mathrm{PR}}_{\mathrm{SF}}^{2}$, are reported in the last column of Table 8 . The values of $\overline{\mathrm{PR}}_{\mathrm{SF}}^{2}$ are much smaller than the values of $\overline{\mathrm{PR}}_{\mathrm{CF}}^{2}$. The average values, $1.17 \%$ for Asian emerging markets and $1.35 \%$ for Asian developed markets, are similar to those from the "market model" for individual stock liquidity in previous studies. ${ }^{15}$ One can think of several explanations for the large differences between $\overline{\mathrm{PR}}_{\mathrm{CF}}^{2}$ and $\overline{\mathrm{PR}}_{\mathrm{SF}}^{2}$. First, as shown in Tables 6 and 7, unexpected regional volatility is a significant liquidity factor for most markets. The lagged global return is significant for some markets. Second, cross-market liquidity commonality is likely to be driven by several sub-regional factors, each having different levels of impact. Using a single global aggregation reduces its explanatory power for local market liquidity. Third, Table 7 shows that the expected and unexpected components of liquidity factors have different liquidity impact. The decomposition can better capture the co-movements between the local market liquidity and the common liquidity factors, thus increasing the partial $\mathrm{R}^{2} \mathrm{~s}$. While not reported here, the coefficients of $\mathrm{L}_{\mathrm{SF}, \mathrm{t}}$ are all positive, and are significant at $5 \%$ for seven of the twelve markets.

\section{Cross-Market Liquidity Commonality in Sub-periods}

Table 5 shows that most markets experienced multiple structural breaks over the sample period. Therefore liquidity commonality in each market may vary significantly over

\footnotetext{
${ }^{15}$ The average unadjusted partial $\mathrm{R}^{2}$ for $\mathrm{L}_{\mathrm{SF}, \mathrm{t}}$ (not reported in Table 8 ) is $1.48 \%$ for emerging markets and $1.53 \%$ for developed markets.
} 
time. Table 9 reports the time trend in liquidity commonality, measured as the weighted averages of the partial $\mathrm{R}^{2} \mathrm{~s}$ of the common factors in two-year sub-periods in the sample. The time trend varies significantly across markets. Several markets had strong surge in recent years, e.g. Hong Kong, Indonesia, Malaysia, and Japan. Korea and Taiwan peaked early. Singapore remained relatively flat over the sample period. India, the Philippines, and Australia have a U-shaped pattern. On average, liquidity commonality of Asian emerging markets was relatively flat until 2008-2010. Liquidity commonality of Asian developed markets has risen steadily since 2002 and a big surge in the last sub-period.

While the 2008-2009 period had the most structural breaks in Table 5, breaks do not always correspond to major market cycles, e.g. the global financial crisis. For investors and policymakers, it is of interest to know how liquidity commonality varies over broad market cycles. Table 10 divides the sample period into four market cycles based on Figure 1: a bear market from the start of the sample to the end of January 2003, a prolonged bull run from February 2003 to the end of September 2007, the global financial crisis from October 2007 to January 2009, and the market rebound in the remaining sample period. On average, there is no significant difference in liquidity commonality in the first bull-bear cycles. During the global financial crisis, many markets experienced sharp rises in liquidity commonality. On average India, Indonesia, Malaysia, Australia, Hong Kong, and Japan doubled their liquidity commonality with outside world. On the other hand, commonality in Korea, the Philippines, Taiwan, and Singapore either remained unchanged or declined. Asian developed markets are more affected by the crisis than Asian emerging markets. After the crisis, commonality remained the same or declined for six of the twelve markets. It began to rise in Korea and the Philippines, and continued to increase in Malaysia, Thailand, Australia, and Japan. 


\section{Conclusion}

Using a multi-factor model, this paper estimates cross-market liquidity commonality among Asian stock markets. Over the sample period from January 2000 to April 2010, common liquidity factors account for $9.4 \%$ of daily liquidity variations in Asian emerging markets and $13.7 \%$ in Asian developed markets. These percentages rise to $14 \%$ and $21 \%$ respectively in the last two years of the sample period and are considerably larger than previously documented for cross-asset liquidity commonality. The study also shows that regional factors affect liquidity commonality through shocks in liquidity and volatility, while global factors affect liquidity commonality through volatility and return. Cross-market liquidity commonality in Asia increased significantly during and after the recent global financial crisis.

The large and rising liquidity commonality across regional markets has potential implications international investors, economic policymakers, and market regulators. Liquidity cycles in different markets are likely to be more synchronized than expected, simultaneous affecting asset prices and portfolio investments in these markets. Liquidity commonality may play a role in the vanishing liquidity during market distress, which in turn may affect real economic activities. Future research should examine the reasons behind the cross-sectional differences and time-series variations in liquidity commonality, and explore the potential need and mechanism for regional regulatory coordination in managing liquidity risk. 


\section{Reference}

Acharya, V., and L. Pedersen, 2005, “Asset Pricing with Liquidity Risk," Journal of Financial Economics 77, 375-410.

Acharya, V., and S. Schaefer, 2006, "Liquidity Risk and Correlation Risk: Implications for Risk Management.” Working Paper, London Business School.

Alizadeh, S., M. W. Brandt, and F. X. Diebold, 2002, "Range-Based Estimation of Stochastic Volatility Models," Journal of Finance 57, 1047-1091.

Amihud, Y., 2002, "Illiquidity and Stock Returns: Cross-section and Time-series Effects," Journal of Financial Markets 5, 31-56.

Amihud, Y., and H. Mendelson, 1986, "Asset pricing and the bid-ask spread," Journal of Financial Economics 17, 223-249.

Andersen, T. G., 1996, "Return Volatility and Trading Volume: An Information Flow Interpretation of Stochastic Volatility," Journal of Finance, 51, 169-204.

Andersen, T. G., T. Bollerslev, and F. X. Diebold, 2007, "Roughing It Up: Including Jump Components in the Measurement, Modeling, and Forecasting of Return Volatility," Review of Economics and Statistics 89, 701-720.

Andersen, T. G., T. Bollerslev, F. X. Diebold and P. Labys, 2003, "Modeling and Forecasting Realized Volatility," Econometrica 71, 579-625.

Andersen, T. G., T. Bollerslev and X. Huang (2006): “A Semiparametric Framework for Modelling and Forecasting Jumps and Volatility in Speculative Prices." Working paper, Duke University.

Andrews, D.W. K., and W. Ploberger, 1994, "Optimal Tests When a Nuisance Parameter Is Present Only Under the Alternative," Econometrica 62, pp. 1383-1414.

Avramov, D., T. Chordia, and A. Goyal, 2006, "Liquidity and Autocorrelations in Individual Stock Returns," Journal of Finance 61, 2365-2394.

Bollerslev, T, and D., Jubinski, 1999, "Equity Trading Volume and Volatility: Latent Information Arrivals and Common Long-Run Dependencies," Journal of Business \& Economic Statistics 17, 9-21.

Bollerslev, T., U. Kretschmer, C. Pigorsch, and G. E. Tauchen (2009), “A Discrete-Time Model for Daily S\&P 500 Returns and Realized Variations: Jumps and Leverage Effects", Journal of Econometrics, 50(2), 151-66.

Borio, C., 2004, "Market distress and vanishing liquidity: anatomy and policy options," BIS Working Papers No 158.

Brockman, P., and D.Y. Chung, 2002, "Commonality in liquidity: Evidence from an orderdriven market structure," Journal of Financial Research 25, 521-539.

Brockman, P., D.Y. Chung, and C. Pérignon, 2009, "Commonality in Liquidity: A Global Perspective," Journal of Financial and Quantitative Analysis 44, 851-882.

Brunnermeier, M. K., 2009, "Deciphering the Liquidity and Credit Crunch 2007-2008," Journal of Economic Perspectives 23, 77-100.

Brunnermeier, M. and L. Pedersen, 2009, "Market Liquidity and Funding Liquidity," Review of Financial Studies 22, 2201-2238.

Chordia, T., R. Roll, and A. Subrahmanyam, 2000, “Commonality in liquidity," Journal of Financial Economics 56, 3-28.

Chordia, T., A. Sarkar, and A. Subrahmanyam, 2005, "An Empirical Analysis of Stock and Bond Market Liquidity," Review of Financial Studies 18, 85-129.

Chordia, T., R. Roll, and A. Subrahmanyam, 2008, "Liquidity and Market Efficiency", Journal of Financial Economics 87, 249-268.

Copeland, T. E., and D. Galai, 1983, "Information Effects on the Bid-Ask Spread," Journal of Finance 38, 1457-1469. 
Corsi, F, 2009, "A Simple Approximate Long-Memory Model of Realized Volatility," Journal of Financial Econometrics, 7(2), 174-196.

Corsi, F., U. Kretschmer, S. Mittnik and C. Pigorsch, 2005, "The Volatility of Realized Volatility", Econometric Reviews 27, 46-78.

Das, S., and P. Hanouna, 2009, "Hedging credit: equity liquidity matters," Journal of Financial Intermediation 18, 112-123.

Fabre, J., and A. Frino, 2004, "Commonality in liquidity: Evidence from the Australian Stock Exchange," Accounting and Finance 44, 357-368.

Forsberg, L., and E. Ghysels, 2006, "Why do absolute returns predict volatility so well?" Journal of Financial Econometrics 6, 31-67.

Galariotis, E.C., and E. Giouvris, 2007, "Liquidity commonality in the London Stock Exchange," Journal of Business Finance and Accounting 34, 374-388.

Gorton, G., 2009, "Information, liquidity, and the (ongoing) panic of 2007," NBER working paper 14649.

Goyenko, R., C. W. Holden, and C. A. Trzcinka, 2009, "Do liquidity measures measure liquidity?" Journal of Financial Economics 92, 153-181.

Greene, W. H., 2008, "Econometric Analysis," 6 ${ }^{\text {th }}$ edition, Prentice Hall.

Hamao, Y., R.W. Masulis, and V. Ng, 1990, "Correlations in Price Changes and Volatility across International Stock Markets," Review of Financial Studies 3, 281-307.

Hameed, A., W. Kang, and S. Viswanathan, 2010, "Stock Market Declines and Liquidity," Journal of Finance 65, 257-293.

Hansen, B. E., 1997, "Approximate Asymptotic P Values for Structural Change Tests," Journal of Business and Economic Statistics 12, 60-67.

Hasbrouck, J., 2009, Trading Costs and Returns for U.S. Equities: Estimating Effective Costs from Daily Data, Journal of Finance 64, 1445 - 1477.

Hasbrouck, J., and D. J. Seppi, 2001, "Common factors in prices, order flows, and liquidity," Journal of Financial Economics 59, 383-411.

Huberman, G., and D. Halka, 2001, "Systematic Liquidity," Journal of Financial Research 24, 161-178.

Jones, C., G. Kaul, and M. Lipson, 1994, Transactions, volume, and volatility, Review of Financial Studies, 7: 631-651.

Kamara, A., X. Lou, and R. Sadka, 2008, "The Divergence of Liquidity Commonality in the Cross-Section of Stocks," Journal of Financial Economics 89, 444-466.

Karolyi, G. A., K-H Lee, and M. A. van Dijk, 2009, "Commonality in Returns, Liquidity, and Turnover Around the World," manuscript, Ohio State University.

Koch, A., S. Ruenzi, and L. Starks, 2009, "Commonality in Liquidity: A Demand-side Explanation," working paper, University of Texas at Austin.

Korajczyk, R.A., and R. Sadka, 2008, "Pricing the Commonality across Alternative Measures of Liquidity," Journal of Financial Economics 87, 45-72.

Kyle, P. 1985, "Continuous Auctions and Insider Trading," Econometrica 53, 1315-1335.

Lesmond, D. A., 2005, "Liquidity of emerging markets," Journal of Financial Economics 77, 411-452.

Lesmond, D., J. Ogden, and C. Trzcinka, 1999, "A new estimate of transaction costs," Review of Financial Studies 12, 1113-1141.

Levy-Yeyati, E., S. Schmukler, and N. Van Horen, 2008, "Emerging Market Liquidity and Crisis," Journal of the European Economic Association 6, 668-682.

Lin, C., 2010, "Financial Liberalization and Liquidity Commonality," working paper, National University of Singapore.

Lo, A.W., 1991, “Long-term memory in stock market prices," Econometrica 59, 1279-1313. 
Mandelbrot, B., 1972, "Statistical Methodology for Non-Periodic Cycles: From the Covariance to R/S Analysis," Annals of Economic and Social Measurement 1, 259290.

Maheu, J. M. and T. H. McCurdy, 2010, "Do High-frequency Measures of Volatility Improve Forecasts of Return Distributions", forthcoming Journal of Econometrics.

Müller, U., M. Dacorogna, R. Davé, R. Olsen, O. Pictet, and J. von Weizsacker, 1997, "Volatilities of Different Time Resolutions - Analyzing the Dynamics of Market Components," Journal of Empirical Finance 4, 213-239.

$\mathrm{Ng}$, A., 2000, "Volatility spillover effects from Japan and the U.S. to the Pacific-Basin," Journal of International Money and Finance 19, 207- 233.

Pastor, L., and R. Stambaugh, 2003, "Liquidity risk and expected stock returns," Journal of Political Economy 111, 642-685.

Plerou, V., P. Gopikrishnan, and H. E. Stanley, 2005, "Quantifying fluctuations in market liquidity: Analysis of the bid-ask spread," Physical Review E 71, 046131.

Pukthuanthong-Le, K., and N. Visaltanachoti, 2009, "Commonality in liquidity: Evidence from the Stock Exchange of Thailand," Pacific-Basin Finance Journal 17, 80-99.

Qin, Y., 2006, "Liquidity and Commonality in Emerging Markets," working paper, National University of Singapore.

Sadka, R., 2006, "Momentum and post-earnings announcement drift anomalies: The role of liquidity risk," Journal of Financial Economics 80, 309-349.

Wang, J., 1999, "Asymmetric Information and the Bid-Ask Spread: An Empirical Comparison between Automated Order Execution and Open Outcry Auction," Journal of International Financial Markets, Institutions and Money 9, 115-128.

Wang, G., and J. Yau, 2000, "Trading volume, bid-ask spread, and price volatility in futures markets," Journal of Futures Markets 20, 943 - 970.

Watanabe, A., and M. Watanabe, 2008, "Time-Varying Liquidity Risk and the Cross-Section of Stock Returns," Review of Financial Studies 21, 2449-2486.

Zhang, Z, J Cai, and Y. Cheung, 2009, "Explaining country and cross-border liquidity commonality in international equity markets," Journal of Futures Markets 29, 630652. 
Table 1: Markets and Indices

\begin{tabular}{lll}
\hline \multicolumn{1}{c}{ Market } & & \multicolumn{1}{c}{ Index } \\
\hline China & CH & The Shanghai Composite Index \\
India & IN & The SENSEX Index \\
Indonesia & ID & The Jakarta Composite Index \\
Korea & KO & The KOSPI Index \\
Malaysia & MA & The Kurla Lumpur Composite Index \\
Philippines & PH & The PSE Index \\
Taiwan & TW & The Taiwan Weighted Index \\
Thailand & TH & The SET Index \\
Australia & AU & The All Ordinaries Index \\
Hong Kong & HK & The Hang Seng Index \\
Japan & JP & The Nikkei 225 Index \\
Singapore & SG & The Straits Times Index \\
United Kingdom & UK & The FTSE 100 Index \\
United States & US & The S\&P 500 Index \\
\hline \hline
\end{tabular}


Table 2: Summary Statistics of Daily Variables

$\rho(1)$ is the first-order autocorrelation. Q5 is the Ljung-Box Q statistic for five lags. ADF is the augmented Dickey-Fuller test.

\begin{tabular}{|c|c|c|c|c|c|c|c|}
\hline & Mean & St Dev & Skew & Kurt & $\rho(1)$ & Q5 & ADF \\
\hline \multicolumn{8}{|c|}{ Return (\%) } \\
\hline $\mathrm{CH}$ & 0.029 & 1.72 & -0.08 & 6.92 & 0.011 & 10.3 & -16.6 \\
\hline IN & 0.046 & 1.77 & -0.19 & 8.84 & 0.074 & 20.1 & -16.2 \\
\hline ID & 0.058 & 1.54 & -0.67 & 8.69 & 0.133 & 45.8 & -17.2 \\
\hline $\mathrm{KO}$ & 0.020 & 1.85 & -0.54 & 7.57 & 0.023 & 8.67 & -17.4 \\
\hline MA & 0.019 & 0.96 & -0.85 & 11.8 & 0.168 & 75.0 & -15.8 \\
\hline $\mathrm{PH}$ & 0.017 & 1.45 & 0.52 & 18.7 & 0.123 & 46.1 & -16.8 \\
\hline TW & -0.003 & 1.61 & -0.14 & 4.85 & 0.057 & 18.4 & -17.5 \\
\hline $\mathrm{TH}$ & 0.017 & 1.54 & -0.75 & 11.8 & 0.027 & 20.0 & -16.3 \\
\hline Mean & 0.025 & 1.56 & -0.34 & 9.90 & 0.077 & 30.5 & -16.7 \\
\hline $\mathrm{AU}$ & 0.017 & 1.02 & -0.70 & 10.6 & -0.037 & 12.7 & -17.2 \\
\hline HK & 0.008 & 1.70 & -0.04 & 10.5 & -0.019 & 5.67 & -17.4 \\
\hline JP & -0.021 & 1.63 & -0.30 & 9.25 & -0.035 & 6.40 & -18.1 \\
\hline $\mathrm{SG}$ & 0.005 & 1.34 & -0.31 & 7.87 & 0.018 & 4.70 & -17.0 \\
\hline Mean & 0.002 & 1.42 & -0.34 & 9.55 & -0.018 & 7.37 & -17.4 \\
\hline UK & -0.007 & 1.33 & -0.14 & 9.17 & -0.067 & 69.8 & -16.9 \\
\hline US & -0.006 & 1.39 & -0.11 & 10.7 & -0.086 & 45.8 & -17.9 \\
\hline Mean & -0.007 & 1.36 & -0.12 & 9.96 & -0.076 & 57.8 & -17.4 \\
\hline \multicolumn{8}{|c|}{ Volume (Billion) } \\
\hline $\mathrm{CH}$ & 4.31 & 4.79 & 1.38 & 4.0 & 0.97 & 11124 & -5.1 \\
\hline IN & 0.04 & 0.03 & 1.39 & 5.5 & 0.84 & 8075 & -4.6 \\
\hline ID & 1.85 & 2.11 & 3.26 & 19.0 & 0.91 & 8989 & -6.8 \\
\hline $\mathrm{KO}$ & 0.45 & 0.22 & 2.66 & 15.3 & 0.86 & 8391 & -5.4 \\
\hline MA & 0.12 & 0.11 & 2.43 & 10.9 & 0.91 & 9298 & -5.4 \\
\hline $\mathrm{PH}$ & 0.22 & 0.27 & 3.76 & 25.5 & 0.73 & 5423 & -8.7 \\
\hline TW & 3.20 & 1.38 & 1.21 & 5.0 & 0.87 & 7810 & -6.4 \\
\hline $\mathrm{TH}$ & 1.63 & 1.32 & 1.29 & 5.4 & 0.90 & 8416 & -8.0 \\
\hline Mean & 1.48 & 1.28 & 2.17 & 11.3 & 0.87 & 8441 & -6.3 \\
\hline AU & 0.68 & 0.38 & 2.04 & 15.2 & 0.84 & 8120 & -9.1 \\
\hline HK & 0.92 & 1.13 & 4.12 & 49.9 & 0.80 & 7321 & -7.4 \\
\hline JP & 0.96 & 0.48 & 0.64 & 2.9 & 0.90 & 9338 & -8.9 \\
\hline $\mathrm{SG}$ & 0.19 & 0.13 & 2.85 & 27.5 & 0.74 & 6188 & -8.8 \\
\hline Mean & 0.69 & 0.53 & 2.41 & 23.9 & 0.82 & 7742 & -8.6 \\
\hline UK & 1.46 & 0.49 & 0.47 & 4.9 & 0.71 & 4724 & -8.0 \\
\hline US & 2.43 & 1.26 & 1.58 & 5.6 & 0.92 & 9936 & -6.4 \\
\hline Mean & 1.95 & 0.87 & 1.02 & 5.2 & 0.82 & 7330 & -7.2 \\
\hline
\end{tabular}


Table 2 - Continued

\begin{tabular}{|c|c|c|c|c|c|c|c|}
\hline & Mean & St Dev & Skew & Kurt & $\begin{array}{l}\rho(1) \\
\end{array}$ & Q5 & ADF \\
\hline \multicolumn{8}{|c|}{ Volatility (\%) } \\
\hline $\mathrm{CH}$ & 1.99 & 1.27 & 1.88 & 8.06 & 0.52 & 2632 & -9.2 \\
\hline IN & 2.03 & 1.35 & 2.76 & 17.3 & 0.63 & 3275 & -8.4 \\
\hline ID & 1.69 & 1.05 & 2.44 & 13.0 & 0.49 & 1516 & -10.5 \\
\hline $\mathrm{KO}$ & 1.95 & 1.19 & 2.77 & 19.1 & 0.61 & 3815 & -7.6 \\
\hline MA & 1.06 & 0.69 & 2.55 & 14.0 & 0.56 & 2450 & -10.2 \\
\hline $\mathrm{PH}$ & 1.29 & 0.80 & 3.23 & 27.0 & 0.28 & 581 & -12.0 \\
\hline TW & 1.67 & 0.98 & 1.71 & 7.96 & 0.47 & 2292 & -8.1 \\
\hline $\mathrm{TH}$ & 1.63 & 1.05 & 4.32 & 52.3 & 0.48 & 1666 & -9.7 \\
\hline Mean & 1.66 & 1.05 & 2.71 & 19.9 & 0.50 & 2278 & -9.5 \\
\hline $\mathrm{AU}$ & 1.06 & 0.78 & 2.93 & 17.1 & 0.60 & 4361 & -6.6 \\
\hline $\mathrm{HK}$ & 1.57 & 1.06 & 3.77 & 35.4 & 0.58 & 3655 & -6.2 \\
\hline $\mathrm{JP}$ & 1.58 & 0.99 & 3.23 & 23.1 & 0.53 & 3038 & -6.7 \\
\hline SG & 1.34 & 0.88 & 3.07 & 21.9 & 0.59 & 3388 & -6.8 \\
\hline Mean & 1.39 & 0.93 & 3.25 & 24.4 & 0.57 & 3610 & -6.6 \\
\hline UK & 1.60 & 1.12 & 2.54 & 13.5 & 0.67 & 5324 & -5.6 \\
\hline US & 1.56 & 1.14 & 2.99 & 17.5 & 0.65 & 5326 & -5.1 \\
\hline Mean & 1.58 & 1.13 & 2.76 & 15.5 & 0.66 & 5325 & -5.4 \\
\hline \multicolumn{8}{|c|}{ Liquidity $=\ln (1+v / \sigma)$} \\
\hline $\mathrm{CH}$ & 0.97 & 0.60 & 0.92 & 3.12 & 0.90 & 9371 & -5.7 \\
\hline IN & 0.03 & 0.02 & 1.75 & 6.53 & 0.68 & 5258 & -5.2 \\
\hline ID & 0.70 & 0.49 & 0.95 & 3.39 & 0.84 & 7904 & -7.0 \\
\hline $\mathrm{KO}$ & 0.25 & 0.13 & 1.14 & 5.58 & 0.59 & 3760 & -6.6 \\
\hline MA & 0.12 & 0.09 & 1.77 & 9.18 & 0.73 & 6402 & -8.2 \\
\hline $\mathrm{PH}$ & 0.17 & 0.18 & 3.08 & 18.7 & 0.68 & 4954 & -8.5 \\
\hline TW & 1.16 & 0.44 & 0.24 & 2.42 & 0.73 & 5845 & -6.3 \\
\hline $\mathrm{TH}$ & 0.72 & 0.47 & 0.47 & 2.64 & 0.84 & 8184 & -6.4 \\
\hline Mean & 0.51 & 0.30 & 1.29 & 6.45 & 0.75 & 6460 & -6.7 \\
\hline AU & 0.56 & 0.26 & 0.70 & 3.34 & 0.56 & 3975 & -6.6 \\
\hline HK & 0.43 & 0.33 & 1.10 & 3.81 & 0.82 & 8331 & -6.7 \\
\hline $\mathrm{JP}$ & 0.55 & 0.30 & 0.74 & 3.09 & 0.75 & 6575 & -6.4 \\
\hline SG & 0.16 & 0.10 & 1.65 & 9.28 & 0.65 & 4912 & -7.4 \\
\hline Mean & 0.42 & 0.25 & 1.05 & 4.88 & 0.70 & 5948 & -6.8 \\
\hline UK & 0.76 & 0.35 & 0.52 & 2.59 & 0.74 & 6832 & -4.8 \\
\hline US & 1.04 & 0.38 & 0.39 & 2.71 & 0.67 & 6043 & -6.6 \\
\hline Mean & 0.90 & 0.37 & 0.46 & 2.65 & 0.71 & 6437 & -5.7 \\
\hline
\end{tabular}


Table 3: Summary Statistics for the Adjusted Daily Liquidity

$\rho(1)$ is the first-order autocorrelation. Q5 is the Ljung-Box Q statistic for five lags. ADF is the augmented Dickey-Fuller test. MRS is the modified R/S test.

\begin{tabular}{|c|c|c|c|c|c|c|c|c|}
\hline & Mean & St Dev & Skew & Kurt & $\rho(1)$ & Q5 & ADF & MRS \\
\hline \multicolumn{9}{|c|}{ Liquidity $=\ln (1+v / \sigma)$} \\
\hline $\mathrm{CH}$ & 0.97 & 0.60 & 0.59 & 3.05 & 0.69 & 4642 & -6.9 & 12 \\
\hline IN & 0.03 & 0.02 & 1.73 & 7.48 & 0.63 & 4335 & -6.1 & 493 \\
\hline ID & 0.71 & 0.49 & 0.84 & 4.17 & 0.67 & 3923 & -7.7 & 10 \\
\hline $\mathrm{KO}$ & 0.25 & 0.13 & 1.14 & 5.23 & 0.54 & 3055 & -6.9 & 58 \\
\hline MA & 0.12 & 0.09 & 2.56 & 26.0 & 0.49 & 2544 & -8.6 & 66 \\
\hline $\mathrm{PH}$ & 0.17 & 0.18 & 2.62 & 14.0 & 0.62 & 3727 & -8.6 & 42 \\
\hline TW & 1.16 & 0.44 & 0.42 & 2.96 & 0.60 & 3274 & -7.7 & 13 \\
\hline $\mathrm{TH}$ & 0.72 & 0.47 & 0.52 & 2.97 & 0.63 & 3790 & -7.3 & 13 \\
\hline Mean & 0.52 & 0.30 & 1.30 & 8.23 & 0.61 & 3661 & -7.5 & 88 \\
\hline $\mathrm{AU}$ & 0.56 & 0.26 & 0.76 & 3.65 & 0.38 & 1779 & -7.7 & 25 \\
\hline HK & 0.44 & 0.33 & 1.22 & 6.30 & 0.46 & 2264 & -7.1 & 27 \\
\hline JP & 0.55 & 0.30 & 0.86 & 3.95 & 0.55 & 3153 & -6.9 & 24 \\
\hline $\mathrm{SG}$ & 0.16 & 0.10 & 1.61 & 11.9 & 0.41 & 1526 & -8.4 & 61 \\
\hline Mean & 0.43 & 0.25 & 1.11 & 6.44 & 0.45 & 2180 & -7.5 & 34 \\
\hline UK & 0.76 & 0.35 & 0.28 & 2.84 & 0.55 & 3796 & -6.5 & 22 \\
\hline US & 1.04 & 0.38 & 0.31 & 2.80 & 0.34 & 1745 & -7.2 & 16 \\
\hline Mean & 0.90 & 0.37 & 0.29 & 2.82 & 0.44 & 2771 & -6.8 & 19 \\
\hline
\end{tabular}


Table 4: A Heterogeneous Autoregressive Model for Daily Liquidity

$$
\mathrm{L}_{\mathrm{i}, \mathrm{t}}=\beta_{0}+\beta_{1} \mathrm{~L}_{\mathrm{i}, \mathrm{t}-1}^{\mathrm{D}}+\beta_{2} \mathrm{~L}_{\mathrm{i}, \mathrm{t}-1}^{\mathrm{W}}+\beta_{3} \mathrm{~L}_{\mathrm{i}, \mathrm{t}-1}^{\mathrm{M}}+\beta_{4} \mathrm{~L}_{\mathrm{i}, \mathrm{t}-1}^{\mathrm{Q}}+\varepsilon_{\mathrm{i}, \mathrm{t}}
$$

The $t$ statistics under the estimated coefficients are based on the Newey-West robust covariance with automatic lag selection using Bartlett kernel. Bold numbers are statistical significant at $5 \%$ level.

\begin{tabular}{|c|c|c|c|c|c|c|}
\hline & $\mathrm{L}_{\mathrm{i}, \mathrm{t}-1}^{\mathrm{D}}$ & $\mathrm{L}_{\mathrm{i}, \mathrm{t}-1}^{\mathrm{W}}$ & $\overline{L_{\mathrm{i}, \mathrm{t}-1}^{\mathrm{M}}}$ & $\begin{array}{l}\mathrm{L}_{\mathrm{i}, \mathrm{t}-1}^{\mathrm{Q}} \\
\end{array}$ & $\beta_{0}$ & $\mathrm{R}^{2}$ \\
\hline \multirow[t]{2}{*}{$\mathrm{CH}$} & 0.312 & 0.454 & 0.082 & 0.073 & 0.078 & 0.56 \\
\hline & 11.3 & 10.4 & 1.53 & 1.68 & 3.52 & \\
\hline \multirow[t]{2}{*}{$\mathrm{IN}$} & 0.168 & 0.471 & 0.148 & 0.168 & 0.001 & 0.56 \\
\hline & 5.42 & 9.32 & 2.22 & 2.95 & 2.19 & \\
\hline \multirow[t]{2}{*}{ ID } & 0.326 & 0.366 & 0.165 & 0.053 & 0.064 & 0.50 \\
\hline & 11.8 & 8.49 & 2.96 & 1.16 & 3.95 & \\
\hline \multirow[t]{2}{*}{$\mathrm{KO}$} & 0.121 & 0.435 & 0.314 & 0.028 & 0.026 & 0.41 \\
\hline & 4.07 & 8.12 & 4.65 & 0.49 & 3.94 & \\
\hline \multirow[t]{2}{*}{ MA } & 0.176 & 0.449 & 0.229 & -0.016 & 0.018 & 0.36 \\
\hline & 5.90 & 9.77 & 4.02 & -0.33 & 4.97 & \\
\hline \multirow[t]{2}{*}{$\mathrm{PH}$} & 0.206 & 0.513 & 0.084 & 0.098 & 0.015 & 0.45 \\
\hline & 6.41 & 9.52 & 1.35 & 2.12 & 3.78 & \\
\hline \multirow[t]{2}{*}{ TW } & 0.270 & 0.412 & 0.167 & 0.031 & 0.083 & 0.45 \\
\hline & 9.76 & 8.83 & 3.36 & 0.76 & 4.58 & \\
\hline \multirow[t]{2}{*}{$\mathrm{TH}$} & 0.277 & 0.344 & 0.250 & -0.003 & 0.153 & 0.42 \\
\hline & 10.1 & 7.55 & 4.58 & -0.06 & 4.65 & \\
\hline \multirow[t]{2}{*}{$\mathrm{AU}$} & 0.041 & 0.377 & 0.363 & 0.118 & 0.059 & 0.30 \\
\hline & 1.52 & 7.02 & 5.14 & 1.90 & 3.39 & \\
\hline \multirow[t]{2}{*}{ HK } & 0.102 & 0.303 & 0.473 & 0.029 & 0.039 & 0.37 \\
\hline & 3.67 & 5.43 & 5.65 & 0.42 & 3.12 & \\
\hline \multirow[t]{2}{*}{$\mathrm{JP}$} & 0.160 & 0.314 & 0.353 & 0.083 & 0.048 & 0.40 \\
\hline & 5.80 & 5.75 & 4.57 & 1.36 & 3.42 & \\
\hline \multirow[t]{2}{*}{$\mathrm{SG}$} & 0.159 & 0.323 & 0.286 & 0.113 & 0.019 & 0.29 \\
\hline & 6.35 & 6.31 & 4.30 & 1.98 & 3.73 & \\
\hline
\end{tabular}


Table 5: Structural Break Dates

This table reports structural breaks in equation (5) estimated over the sample period of January 2000 to April 2010. The break dates are reported as Month/Day in a given year.

\begin{tabular}{|c|c|c|c|c|c|c|c|c|c|c|}
\hline & 2000 & 2001 & 2002 & 2003 & 2004 & 2005 & 2006 & 2007 & 2008 & 2009 \\
\hline $\mathrm{CH}$ & & $7 / 13$ & $6 / 20$ & $5 / 15$ & & $7 / 28$ & & $6 / 14$ & $9 / 24$ & $3 / 5$ \\
\hline IN & & $2 / 28 \& 12 / 12$ & & & & $1 / 3$ & & & $4 / 16 \& 12 / 19$ & \\
\hline ID & & & & & & & $8 / 28$ & & $5 / 2 / 08$ & $6 / 12$ \\
\hline $\mathrm{KO}$ & & $9 / 28$ & $11 / 19$ & & $5 / 6$ & & & & & $1 / 30$ \\
\hline MA & & & & $5 / 7$ & & & & & $2 / 20$ & $4 / 27$ \\
\hline $\mathrm{PH}$ & & $7 / 16$ & & & $8 / 6$ & & & & & $3 / 16$ \\
\hline TW & & $5 / 2$ & $10 / 18$ & & & & & & & \\
\hline $\mathrm{TH}$ & & & & $5 / 27$ & $1 / 16 \& 8 / 19$ & & $6 / 7$ & $12 / 13$ & & $3 / 2$ \\
\hline $\mathrm{AU}$ & $6 / 30$ & $9 / 14$ & & & & $3 / 2$ & & $9 / 3$ & $12 / 23$ & \\
\hline HK & & & & & & & $9 / 14$ & & $9 / 24$ & $8 / 11$ \\
\hline JP & & & & & $9 / 9$ & & & $1 / 15 \& 10 / 29$ & & $4 / 27$ \\
\hline $\mathrm{SG}$ & & & & & $2 / 26$ & & & & & \\
\hline
\end{tabular}


Table 6: Weighted Average Parameter Estimates: Local and Global Factors

This table reports the weighted average parameters across structural break sub-periods. The $t$ statistics under the estimated coefficients are based on the Newey-West robust covariance with automatic lag selection using Bartlett kernel. Bold numbers are statistical significant at $5 \%$ level.

\begin{tabular}{|c|c|c|c|c|c|c|c|c|c|c|c|c|c|}
\hline & \multicolumn{7}{|c|}{ Local Factors } & \multicolumn{6}{|c|}{ Global Factors } \\
\hline & $\mathrm{L}_{\mathrm{i}, \mathrm{t}-1}^{\mathrm{D}}$ & $\mathrm{L}_{\mathrm{i}, \mathrm{t}-1}^{\mathrm{W}}$ & $\mathrm{L}_{\mathrm{i}, \mathrm{t}-1}^{\mathrm{M}}$ & $\sigma_{i, t}^{E}$ & $\sigma_{i, t}^{U}$ & $r_{i, t}$ & $r_{i, t-1}^{D}$ & $\mathrm{~L}_{\mathrm{G}, \mathrm{t}-1}^{\mathrm{D}}$ & $\mathrm{L}_{\mathrm{G}, \mathrm{t}-1}^{\mathrm{W}}$ & $\sigma_{\mathrm{G}, \mathrm{t}-1}^{\mathrm{D}}$ & $\sigma_{\mathrm{G}, \mathrm{t}-1}^{\mathrm{W}}$ & $\mathrm{r}_{\mathrm{G}, \mathrm{t}-1}^{\mathrm{D}}$ & $r_{G, t-1}^{W}$ \\
\hline \multirow[t]{2}{*}{$\mathrm{CH}$} & 0.205 & 0.515 & 0.070 & 0.072 & -0.623 & 0.039 & 0.096 & 0.018 & -0.056 & 0.021 & -0.077 & 0.005 & 0.040 \\
\hline & 6.00 & 9.16 & 1.48 & 1.91 & -18.7 & 5.95 & 9.48 & 0.09 & -0.25 & 0.11 & -0.66 & 0.37 & 1.27 \\
\hline \multirow[t]{2}{*}{ IN } & 0.097 & 0.393 & 0.150 & -0.003 & -0.021 & -0.0001 & 0.001 & 0.002 & -0.001 & 0.002 & 0.0002 & 0.001 & 0.0001 \\
\hline & 2.79 & 6.14 & 2.06 & -1.59 & -19.9 & 0.11 & 4.83 & 0.71 & -0.03 & 0.86 & -0.11 & 1.12 & 0.01 \\
\hline \multirow[t]{2}{*}{ ID } & 0.294 & 0.342 & 0.157 & 0.122 & -0.469 & 0.028 & 0.053 & 0.042 & -0.042 & 0.032 & -0.067 & 0.010 & 0.003 \\
\hline & 8.57 & 7.37 & 3.51 & 2.87 & -20.8 & 5.14 & 7.61 & 0.29 & -0.18 & 0.56 & -0.90 & 1.25 & -0.02 \\
\hline \multirow[t]{2}{*}{$\mathrm{KO}$} & 0.047 & 0.471 & 0.255 & -0.024 & -0.179 & 0.002 & 0.009 & 0.002 & -0.004 & 0.002 & 0.018 & -0.001 & 0.016 \\
\hline & 1.53 & 8.28 & 4.85 & -0.70 & -20.8 & 0.48 & 5.35 & -0.41 & 0.07 & -0.28 & 0.91 & -0.53 & 3.00 \\
\hline \multirow[t]{2}{*}{ MA } & 0.148 & 0.428 & 0.112 & 0.012 & -0.101 & 0.009 & 0.012 & 0.005 & -0.002 & 0.011 & -0.010 & 0.002 & 0.001 \\
\hline & 3.40 & 7.41 & 1.52 & 1.32 & -17.1 & 3.40 & 4.37 & 0.29 & -0.07 & 0.89 & -0.62 & 0.75 & 0.34 \\
\hline \multirow[t]{2}{*}{$\mathrm{PH}$} & 0.171 & 0.467 & 0.130 & 0.046 & -0.115 & 0.007 & 0.008 & 0.027 & -0.090 & 0.017 & -0.036 & 0.001 & 0.006 \\
\hline & 3.82 & 6.53 & 1.93 & 2.06 & -12.5 & 2.51 & 2.87 & 0.69 & -1.21 & 0.66 & -0.49 & 0.30 & 0.80 \\
\hline \multirow[t]{2}{*}{ TW } & 0.200 & 0.477 & 0.192 & 0.110 & -0.515 & 0.033 & 0.064 & 0.112 & -0.112 & 0.082 & -0.096 & 0.002 & 0.034 \\
\hline & 7.86 & 11.79 & 5.47 & 3.73 & -23.5 & 6.51 & 10.28 & 2.26 & -1.33 & 2.50 & -2.22 & 0.24 & 2.06 \\
\hline \multirow[t]{2}{*}{$\mathrm{TH}$} & 0.154 & 0.370 & 0.228 & -0.042 & -0.553 & 0.032 & 0.066 & -0.009 & 0.046 & 0.028 & 0.002 & 0.014 & 0.025 \\
\hline & 4.31 & 6.11 & 3.82 & 0.13 & -20.0 & 4.81 & 8.96 & -0.15 & 0.73 & 0.72 & 0.60 & 2.00 & 0.75 \\
\hline \multirow[t]{2}{*}{$\mathrm{AU}$} & 0.038 & 0.143 & 0.106 & -0.275 & -0.381 & -0.005 & 0.009 & 0.073 & 0.024 & 0.045 & 0.027 & 0.001 & 0.004 \\
\hline & 1.25 & 2.18 & 1.12 & -4.67 & -26.6 & -0.63 & 1.35 & 1.74 & 0.36 & 1.57 & 0.62 & 0.07 & 0.23 \\
\hline \multirow[t]{2}{*}{ HK } & 0.070 & 0.283 & 0.323 & -0.083 & -0.391 & 0.012 & 0.026 & 0.081 & -0.114 & 0.126 & -0.109 & -0.007 & 0.036 \\
\hline & 2.38 & 4.35 & 5.36 & -0.09 & -23.6 & 2.21 & 4.71 & 2.34 & -1.60 & 4.60 & -2.41 & -1.67 & 2.93 \\
\hline \multirow[t]{2}{*}{$\mathrm{JP}$} & 0.111 & 0.212 & 0.417 & -0.110 & -0.457 & 0.012 & 0.026 & 0.094 & -0.052 & 0.087 & -0.062 & 0.000 & 0.013 \\
\hline & 3.92 & 4.25 & 7.39 & -2.45 & -26.4 & 4.05 & 5.96 & 1.77 & -0.56 & 2.68 & -1.19 & -0.40 & 1.66 \\
\hline \multirow[t]{2}{*}{$\mathrm{SG}$} & 0.125 & 0.256 & 0.284 & -0.006 & -0.137 & 0.005 & 0.005 & 0.010 & -0.001 & 0.019 & -0.004 & 0.001 & 0.006 \\
\hline & 4.93 & 5.02 & 5.53 & -0.42 & -27.6 & 2.79 & 2.85 & 0.90 & -0.04 & 2.01 & -0.28 & 0.66 & 1.75 \\
\hline
\end{tabular}


Table 7: Weighted Average Parameter Estimates: Advanced and Emerging Markets

This table reports the weighted average parameters across structural break sub-periods. The $t$ statistics under the estimated coefficients are based on the Newey-West robust covariance with automatic lag selection using Bartlett kernel. Bold numbers are statistical significant at $5 \%$ level.

\begin{tabular}{|c|c|c|c|c|c|c|c|c|c|c|c|c|c|}
\hline & \multicolumn{6}{|c|}{ Developed Markets } & \multicolumn{6}{|c|}{ Emerging Markets } & \multirow[b]{2}{*}{$\beta_{0}$} \\
\hline & $\mathrm{L}_{\mathrm{AD}, \mathrm{t}}^{\mathrm{E}}$ & $\mathrm{L}_{\mathrm{AD}, \mathrm{t}}^{\mathrm{U}}$ & $\sigma_{\mathrm{AD}, \mathrm{t}}^{\mathrm{E}}$ & $\sigma_{\mathrm{AD}, \mathrm{t}}^{\mathrm{U}}$ & $r_{A D, t}$ & $r_{A D, t-1}^{D}$ & $\mathrm{~L}_{\mathrm{AE}, \mathrm{t}}^{\mathrm{E}}$ & $\mathrm{L}_{\mathrm{AE}, \mathrm{t}}^{\mathrm{U}}$ & $\sigma_{\mathrm{AE}, \mathrm{t}}^{\mathrm{E}}$ & $\sigma_{\mathrm{AE}, \mathrm{t}}^{\mathrm{U}}$ & $r_{A E, t}$ & $r_{A E, t-1}^{D}$ & \\
\hline \multirow[t]{2}{*}{$\mathrm{CH}$} & 0.073 & 0.089 & 0.098 & 0.030 & -0.021 & -0.009 & 0.178 & 0.078 & 0.069 & 0.027 & 0.011 & 0.003 & 0.028 \\
\hline & 0.31 & 0.68 & 0.70 & 0.48 & -1.26 & -0.45 & 1.28 & 0.64 & 0.77 & 0.48 & 0.77 & 0.05 & -0.29 \\
\hline \multirow[t]{2}{*}{ IN } & 0.002 & 0.008 & 0 & 0.004 & 0 & -0.0001 & 0.002 & -0.001 & 0.001 & 0.001 & 0.0003 & -0.0001 & 0.007 \\
\hline & 0.19 & 2.07 & 0.40 & 2.29 & -0.21 & 0.09 & 0.71 & -0.12 & 0.25 & 0.77 & 0.42 & -0.59 & 1.50 \\
\hline \multirow[t]{2}{*}{ ID } & 0.103 & 0.335 & -0.016 & 0.133 & 0.010 & -0.017 & 0.226 & 0.182 & 0.051 & 0.106 & -0.017 & -0.011 & -0.070 \\
\hline & 0.40 & 3.31 & -0.15 & 2.87 & 0.42 & -1.24 & 2.12 & 2.23 & 0.36 & 2.56 & -1.28 & -0.67 & -0.59 \\
\hline \multirow[t]{2}{*}{$\mathrm{KO}$} & 0.003 & 0.050 & 0.009 & 0.021 & 0.000 & -0.002 & 0.006 & 0.028 & -0.010 & 0.006 & 0.001 & 0.000 & 0.068 \\
\hline & 0.53 & 2.49 & 0.28 & 2.30 & 0.27 & -1.01 & -0.57 & 1.51 & -0.46 & 1.01 & -0.14 & -0.05 & 1.34 \\
\hline \multirow[t]{2}{*}{ MA } & 0.062 & 0.086 & 0.036 & 0.041 & 0.001 & -0.003 & 0.037 & 0.060 & -0.017 & 0.028 & -0.004 & -0.002 & -0.012 \\
\hline & 1.20 & 3.65 & 1.47 & 4.02 & 0.37 & -0.67 & 1.56 & 3.08 & -0.97 & 2.36 & -1.01 & -0.71 & -0.22 \\
\hline \multirow[t]{2}{*}{$\mathrm{PH}$} & 0.091 & 0.084 & -0.003 & 0.043 & 0.001 & 0.001 & 0.032 & 0.035 & 0.018 & 0.024 & -0.001 & -0.002 & 0.035 \\
\hline & 1.27 & 2.43 & 0.00 & 2.31 & 0.00 & -0.03 & 0.54 & 0.82 & 0.38 & 0.89 & 0.00 & -0.39 & 0.57 \\
\hline \multirow[t]{2}{*}{ TW } & 0.192 & 0.347 & -0.022 & 0.096 & 0.004 & -0.011 & -0.123 & 0.200 & -0.010 & 0.123 & -0.006 & -0.020 & 0.042 \\
\hline & 1.29 & 4.49 & -0.14 & 3.01 & 0.58 & -1.28 & -1.76 & 2.98 & -0.06 & 2.96 & -0.57 & -1.25 & 0.67 \\
\hline \multirow[t]{2}{*}{$\mathrm{TH}$} & 0.125 & 0.181 & 0.004 & 0.074 & 0.001 & -0.023 & 0.181 & 0.099 & 0.050 & 0.034 & 0.001 & 0.001 & 0.116 \\
\hline & 0.36 & 1.95 & -0.52 & 1.46 & 0.24 & -2.25 & 1.49 & 0.88 & 0.95 & 0.77 & 0.05 & 0.06 & 0.40 \\
\hline \multirow[t]{2}{*}{$\mathrm{AU}$} & 0.152 & 0.116 & 0.018 & 0.051 & 0.001 & 0.005 & 0.015 & 0.042 & -0.011 & 0.013 & -0.002 & -0.007 & 0.185 \\
\hline & 1.85 & 2.19 & 0.52 & 2.29 & 0.12 & 0.73 & 0.17 & 0.74 & -0.22 & 0.31 & -0.36 & -0.77 & 1.95 \\
\hline \multirow[t]{2}{*}{$\mathrm{HK}$} & 0.181 & 0.270 & 0.047 & 0.156 & -0.009 & -0.011 & 0.200 & 0.263 & 0.073 & 0.167 & 0.006 & -0.008 & -0.025 \\
\hline & 1.15 & 3.22 & 0.53 & 5.33 & -1.17 & -1.22 & 2.18 & 3.46 & 0.05 & 4.02 & 1.00 & -1.05 & -0.58 \\
\hline \multirow[t]{2}{*}{$\mathrm{JP}$} & 0.007 & 0.129 & 0.004 & 0.058 & -0.003 & -0.011 & 0.156 & 0.065 & 0.012 & 0.052 & -0.008 & -0.006 & 0.040 \\
\hline & 0.17 & 2.64 & 0.32 & 2.91 & -0.78 & -1.56 & 2.03 & 1.02 & -0.06 & 1.43 & -1.03 & -0.75 & 0.80 \\
\hline \multirow[t]{2}{*}{$\mathrm{SG}$} & 0.024 & 0.117 & -0.007 & 0.064 & 0.003 & -0.002 & 0.041 & 0.090 & -0.017 & 0.059 & 0.001 & 0.000 & 0.014 \\
\hline & 0.68 & 6.76 & -0.55 & 7.62 & 1.33 & -0.85 & 1.81 & 4.71 & -1.21 & 5.67 & 0.16 & -0.07 & 0.73 \\
\hline
\end{tabular}


Table 8: Common Liquidity Factors and Cross-Market Liquidity Commonality

This table reports the weighted average partial $\mathrm{R}^{2}$ of different factors in explaining the daily variations in local market liquidity. $\mathrm{PR}_{\mathrm{G}}^{2}, \mathrm{PR}_{\mathrm{AD}}^{2}$, and $\mathrm{PR}_{\mathrm{AE}}^{2}$ are the partial $\mathrm{R}^{2} \mathrm{~S}$ of the global factors, factors from Asian developed markets, and factors from Asian emerging markets respectively, in equation (5). $\mathrm{PR}_{\mathrm{CA}}^{2}$ is the partial $\mathrm{R}^{2} \mathrm{~s}$ of the Asian contemporaneous variables. $\mathrm{PR}_{\mathrm{CF}}^{2}$ is the partial $\mathrm{R}^{2} \mathrm{~s}$ of all common factors. $\mathrm{R}^{2}$ is the coefficient of determination of equation (5). $\overline{\mathrm{PR}}_{\mathrm{CF}}^{2}$ is the adjusted partial $\mathrm{R}^{2}$ of the common factors. $\overline{\mathrm{PR}}_{\mathrm{SF}}^{2}$ is the adjusted partial $\mathrm{R}^{2}$ of the single factor in equation (6).

\begin{tabular}{ccccccccc}
\hline \hline & $\mathrm{PR}_{\mathrm{G}}^{2}$ & $\mathrm{PR}_{\mathrm{AD}}^{2}$ & $\mathrm{PR}_{\mathrm{AE}}^{2}$ & $\mathrm{PR}_{\mathrm{CA}}^{2}$ & $\mathrm{PR}_{\mathrm{CF}}^{2}$ & $\mathrm{R}^{2}$ & $\overline{\mathrm{PR}}_{\mathrm{CF}}^{2}$ & $\overline{\mathrm{PR}}_{\mathrm{SF}}^{2}$ \\
\hline $\mathrm{CH}$ & $3.4 \%$ & $2.9 \%$ & $3.7 \%$ & $2.8 \%$ & $9.3 \%$ & $85 \%$ & $3.6 \%$ & $0.76 \%$ \\
$\mathrm{IN}$ & $2.1 \%$ & $3.3 \%$ & $2.6 \%$ & $3.6 \%$ & $8.5 \%$ & $68 \%$ & $4.4 \%$ & $0.26 \%$ \\
$\mathrm{ID}$ & $1.2 \%$ & $3.2 \%$ & $2.2 \%$ & $4.9 \%$ & $8.2 \%$ & $73 \%$ & $5.5 \%$ & $1.71 \%$ \\
$\mathrm{KO}$ & $3.5 \%$ & $2.5 \%$ & $1.6 \%$ & $3.0 \%$ & $8.0 \%$ & $80 \%$ & $4.6 \%$ & $1.47 \%$ \\
$\mathrm{MA}$ & $1.4 \%$ & $5.2 \%$ & $3.8 \%$ & $7.6 \%$ & $12.5 \%$ & $73 \%$ & $9.2 \%$ & $2.57 \%$ \\
$\mathrm{PH}$ & $1.5 \%$ & $2.8 \%$ & $1.5 \%$ & $2.4 \%$ & $6.1 \%$ & $61 \%$ & $3.3 \%$ & $0.15 \%$ \\
$\mathrm{TW}$ & $1.2 \%$ & $3.6 \%$ & $2.1 \%$ & $4.1 \%$ & $8.4 \%$ & $77 \%$ & $6.4 \%$ & $0.99 \%$ \\
$\mathrm{TH}$ & $5.2 \%$ & $4.3 \%$ & $3.8 \%$ & $3.7 \%$ & $13.9 \%$ & $85 \%$ & $9.4 \%$ & $1.44 \%$ \\
Mean & $\mathbf{2 . 4 \%}$ & $3.5 \%$ & $2.7 \%$ & $\mathbf{4 . 0 \%}$ & $\mathbf{9 . 4 \%}$ & $\mathbf{7 5 \%}$ & $5.8 \%$ & $\mathbf{1 . 1 7 \%}$ \\
& & & & & & & & \\
$\mathrm{AU}$ & $4.4 \%$ & $5.0 \%$ & $2.6 \%$ & $4.2 \%$ & $13.4 \%$ & $82 \%$ & $9.6 \%$ & $1.55 \%$ \\
$\mathrm{HK}$ & $3.5 \%$ & $4.1 \%$ & $4.3 \%$ & $7.8 \%$ & $14.7 \%$ & $65 \%$ & $12.3 \%$ & $1.05 \%$ \\
$\mathrm{JP}$ & $3.6 \%$ & $3.2 \%$ & $3.2 \%$ & $4.8 \%$ & $12.5 \%$ & $84 \%$ & $9.3 \%$ & $1.12 \%$ \\
$\mathrm{SG}$ & $1.3 \%$ & $6.1 \%$ & $3.8 \%$ & $10.1 \%$ & $14.3 \%$ & $68 \%$ & $13.0 \%$ & $1.68 \%$ \\
Mean & $\mathbf{3 . 2 \%}$ & $\mathbf{4 . 6 \%}$ & $3.5 \%$ & $\mathbf{6 . 7 \%}$ & $\mathbf{1 3 . 7 \%}$ & $\mathbf{7 5 \%}$ & $\mathbf{1 1 . 1 \%}$ & $\mathbf{1 . 3 5 \%}$ \\
\hline \hline
\end{tabular}


Table 9: Liquidity commonality in 2-year sub-periods

This table reports the liquidity commonality, measured as the partial $\mathrm{R}^{2} \mathrm{~s}$ of the common factors $\left(\mathrm{PR}_{\mathrm{CF}}^{2}\right)$ in equation (5), over 2-year sub-periods.

\begin{tabular}{cccccc}
\hline \hline & $2000-2001$ & $2002-2003$ & $2004-2005$ & $2006-2007$ & $2008-2010$ \\
\hline CH & $7.1 \%$ & $12.0 \%$ & $7.2 \%$ & $8.6 \%$ & $11.5 \%$ \\
IN & $10.0 \%$ & $4.2 \%$ & $5.0 \%$ & $5.8 \%$ & $16.6 \%$ \\
ID & $4.2 \%$ & $4.2 \%$ & $4.2 \%$ & $11.4 \%$ & $16.0 \%$ \\
KO & $7.2 \%$ & $11.8 \%$ & $7.0 \%$ & $5.9 \%$ & $8.1 \%$ \\
MA & $6.3 \%$ & $7.2 \%$ & $10.1 \%$ & $13.4 \%$ & $23.4 \%$ \\
PH & $7.3 \%$ & $6.2 \%$ & $4.2 \%$ & $3.4 \%$ & $8.9 \%$ \\
TW & $15.1 \%$ & $8.4 \%$ & $6.4 \%$ & $6.4 \%$ & $6.4 \%$ \\
TH & $7.1 \%$ & $14.3 \%$ & $12.4 \%$ & $13.5 \%$ & $20.6 \%$ \\
Mean & $\mathbf{8 . 0 \%}$ & $\mathbf{8 . 5 \%}$ & $7.1 \%$ & $\mathbf{8 . 5 \%}$ & $\mathbf{1 3 . 9 \%}$ \\
& & & & & \\
AU & $19.1 \%$ & $6.1 \%$ & $7.9 \%$ & $11.4 \%$ & $22.3 \%$ \\
HK & $9.8 \%$ & $9.8 \%$ & $9.8 \%$ & $17.0 \%$ & $25.5 \%$ \\
JP & $4.9 \%$ & $4.9 \%$ & $8.0 \%$ & $19.9 \%$ & $23.5 \%$ \\
SG & $13.9 \%$ & $13.9 \%$ & $14.5 \%$ & $14.5 \%$ & $14.5 \%$ \\
Mean & $\mathbf{1 1 . 9 \%}$ & $\mathbf{8 . 7 \%}$ & $\mathbf{1 0 . 0 \%}$ & $\mathbf{1 5 . 7 \%}$ & $\mathbf{2 1 . 4 \%}$ \\
\hline \hline
\end{tabular}

* The last sub-period ends on 30 April 2010.

Table 10: Liquidity Commonality in Bull and Bear Markets

This table reports the liquidity commonality, measured as the partial $\mathrm{R}^{2} \mathrm{~s}$ of the common factors $\left(\mathrm{PR}_{\mathrm{CF}}^{2}\right)$ in equation (5), over bull-bear market cycles.

\begin{tabular}{ccccc}
\hline \hline & $\begin{array}{c}\text { Bear Market } \\
2000 / 1-2003 / 1\end{array}$ & $\begin{array}{c}\text { Bull Market } \\
2003 / 2-2007 / 9\end{array}$ & $\begin{array}{c}\text { Bear Market } \\
2007 / 10-2009 / 1\end{array}$ & $\begin{array}{c}\text { Bull Market } \\
2009 / 1-2010 / 4\end{array}$ \\
\hline CH & $9.4 \%$ & $8.2 \%$ & $11.4 \%$ & $11.3 \%$ \\
IN & $8.0 \%$ & $5.1 \%$ & $17.2 \%$ & $13.9 \%$ \\
ID & $4.2 \%$ & $6.7 \%$ & $16.8 \%$ & $14.9 \%$ \\
KO & $8.7 \%$ & $7.7 \%$ & $6.0 \%$ & $10.1 \%$ \\
MA & $6.3 \%$ & $11.0 \%$ & $20.2 \%$ & $24.8 \%$ \\
PH & $6.9 \%$ & $4.3 \%$ & $3.4 \%$ & $13.8 \%$ \\
TW & $13.3 \%$ & $6.4 \%$ & $6.4 \%$ & $6.4 \%$ \\
TH & $7.1 \%$ & $14.7 \%$ & $15.8 \%$ & $24.8 \%$ \\
Mean & $\mathbf{8 . 0 \%}$ & $\mathbf{8 . 0 \%}$ & $\mathbf{1 2 . 1 \%}$ & $\mathbf{1 5 . 0 \%}$ \\
& & & & \\
AU & $14.5 \%$ & $8.6 \%$ & $17.5 \%$ & $26.3 \%$ \\
HK & $9.8 \%$ & $12.3 \%$ & $22.2 \%$ & $28.1 \%$ \\
JP & $4.9 \%$ & $11.3 \%$ & $27.6 \%$ & $20.1 \%$ \\
SG & $13.9 \%$ & $14.4 \%$ & $14.5 \%$ & $14.5 \%$ \\
Mean & $\mathbf{1 0 . 8 \%}$ & $\mathbf{1 1 . 6 \%}$ & $\mathbf{2 0 . 5 \%}$ & $\mathbf{2 2 . 3 \%}$ \\
\hline \hline
\end{tabular}


Figure 1: Asian Stock Market Performance
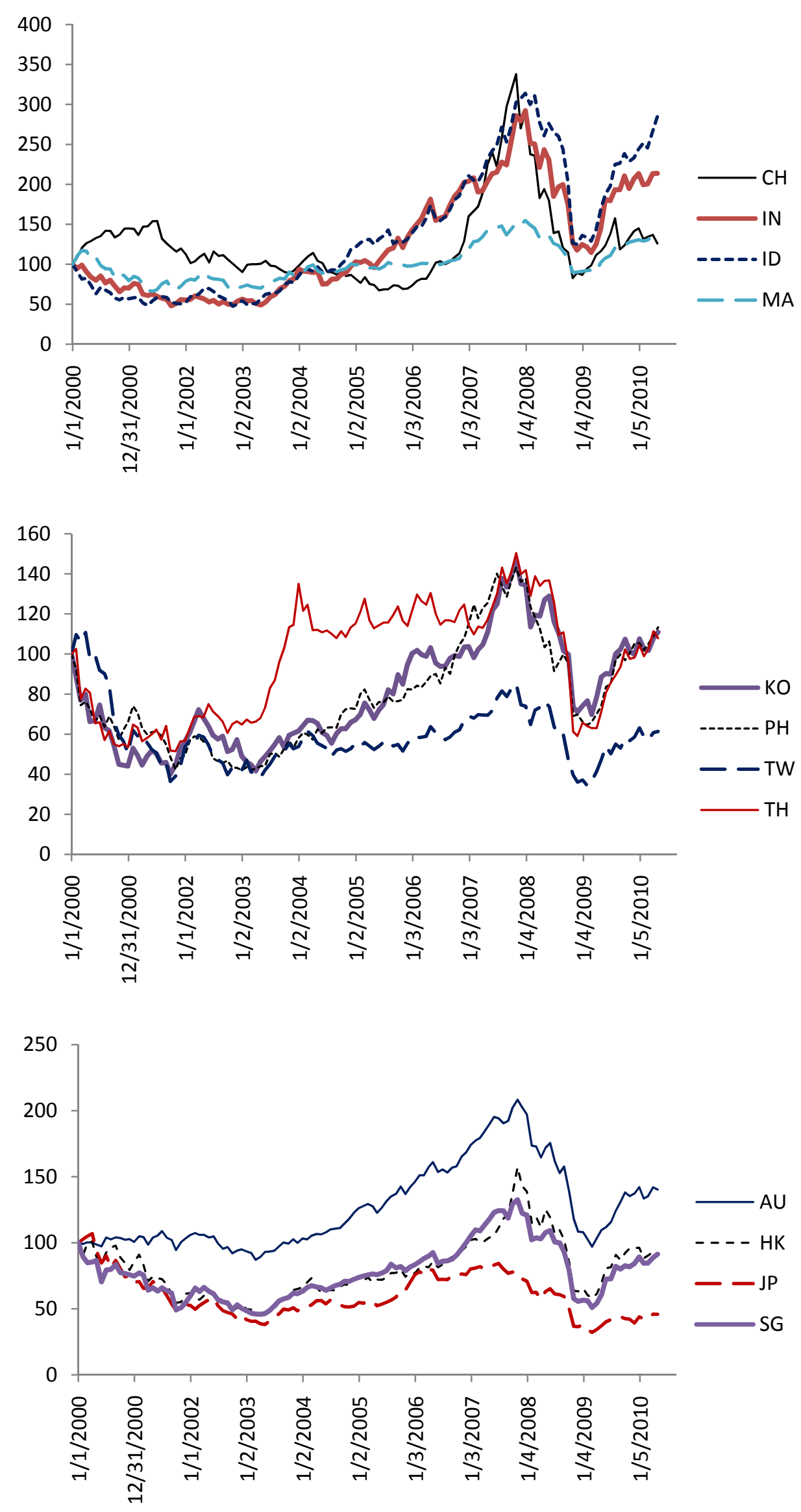
Figure 2: Original and Adjusted Daily Liquidity

Original Daily Liquidity of Australia

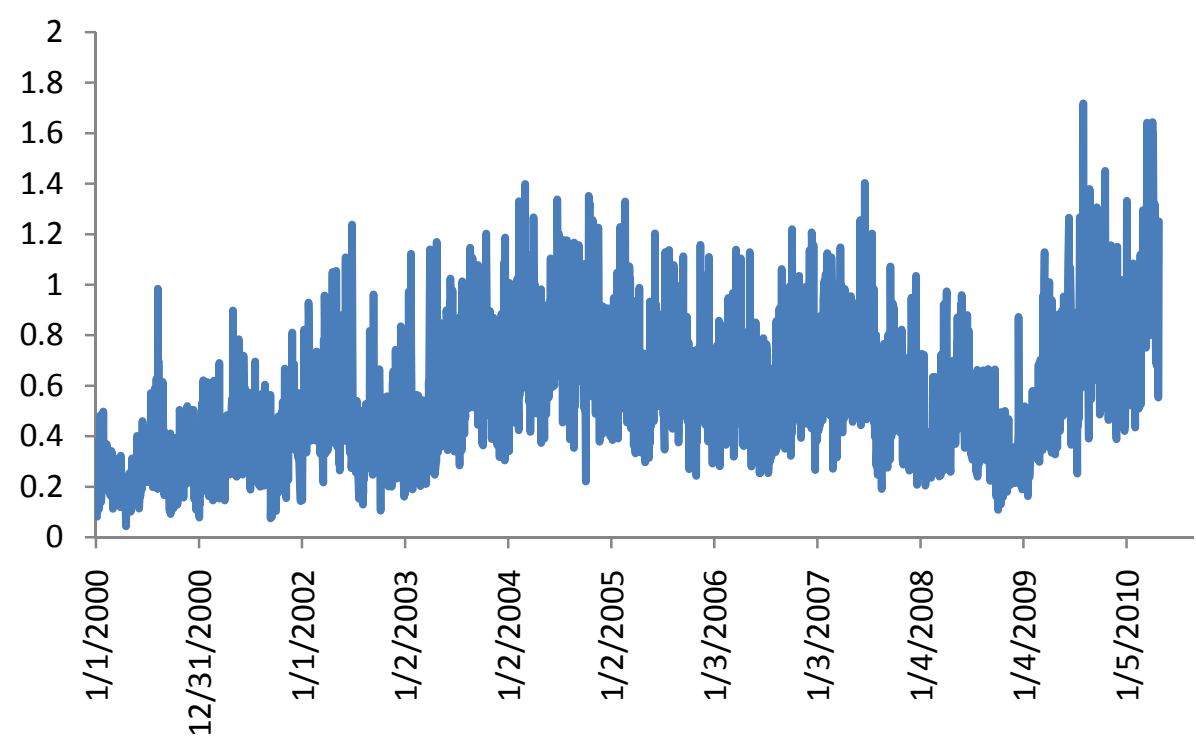

Adjusted Daily Liquidity of Australia

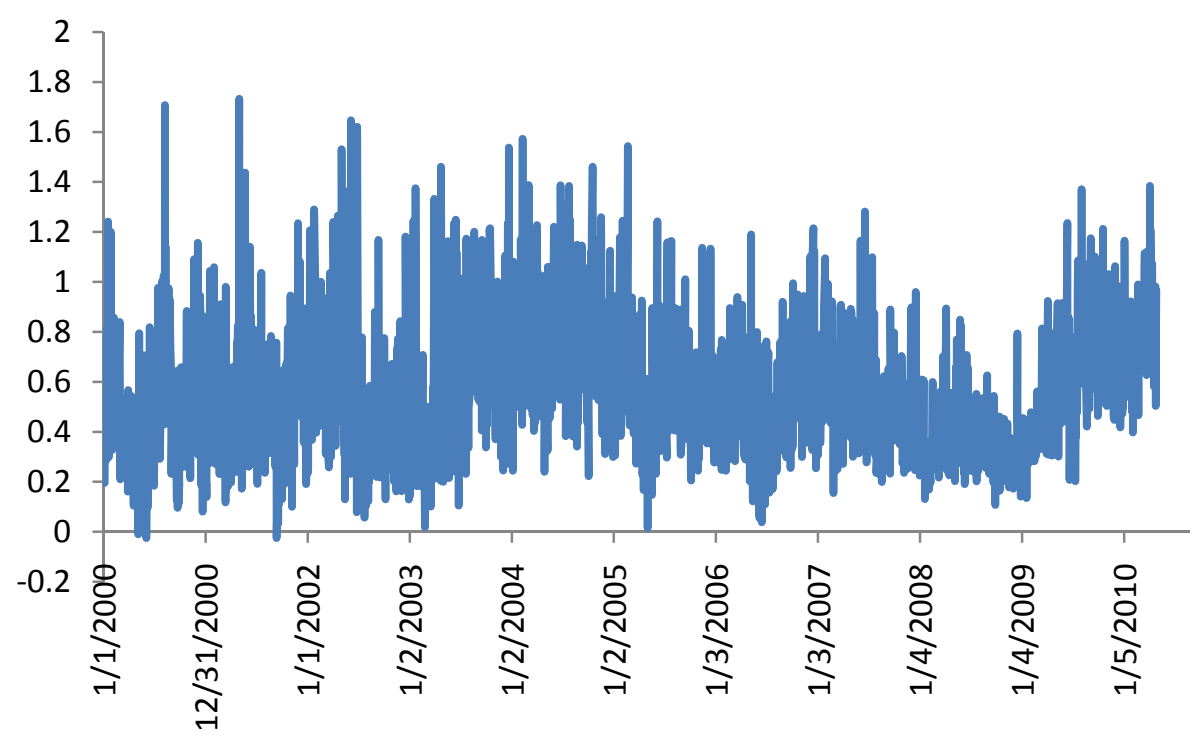


Figure 3: Liquidity Autocorrelation

Panel A: Emerging Markets

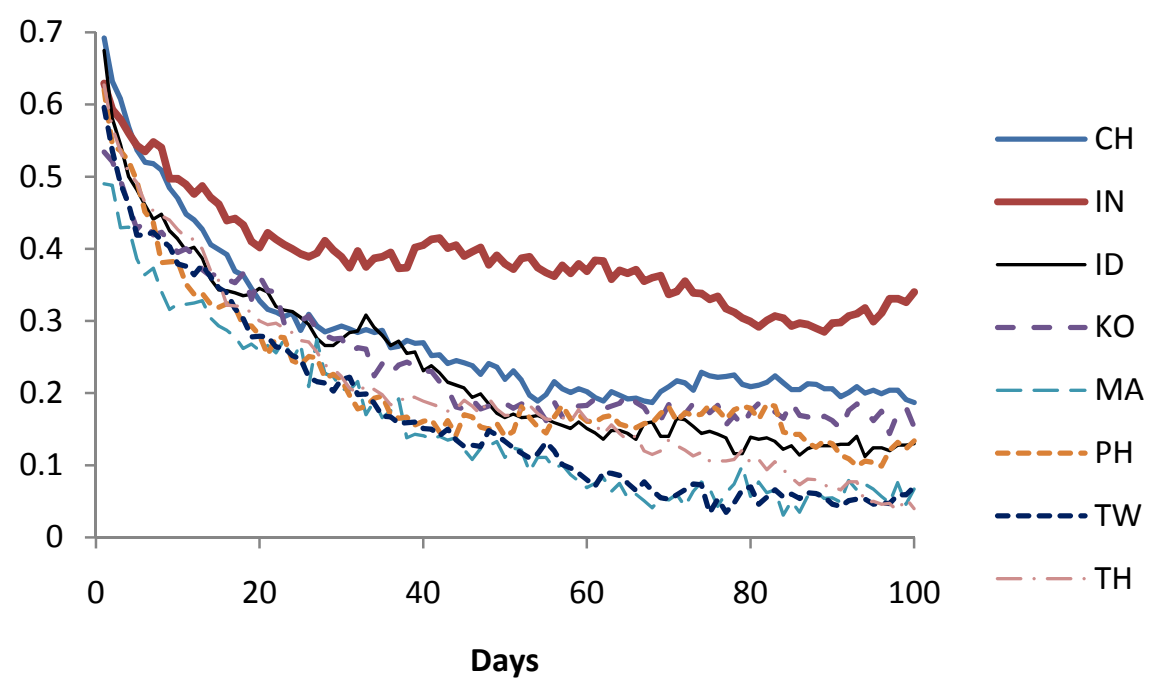

Panel B: Advanced Markets

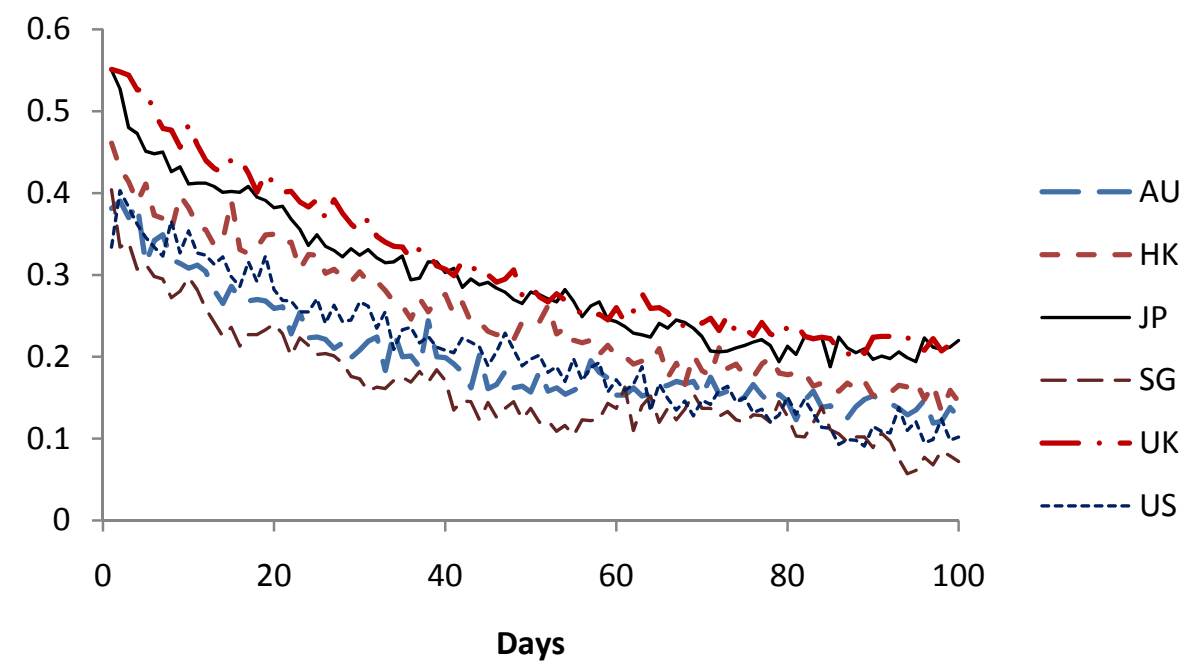

Panel C: Autocorrelation of HAR(3) Residuals

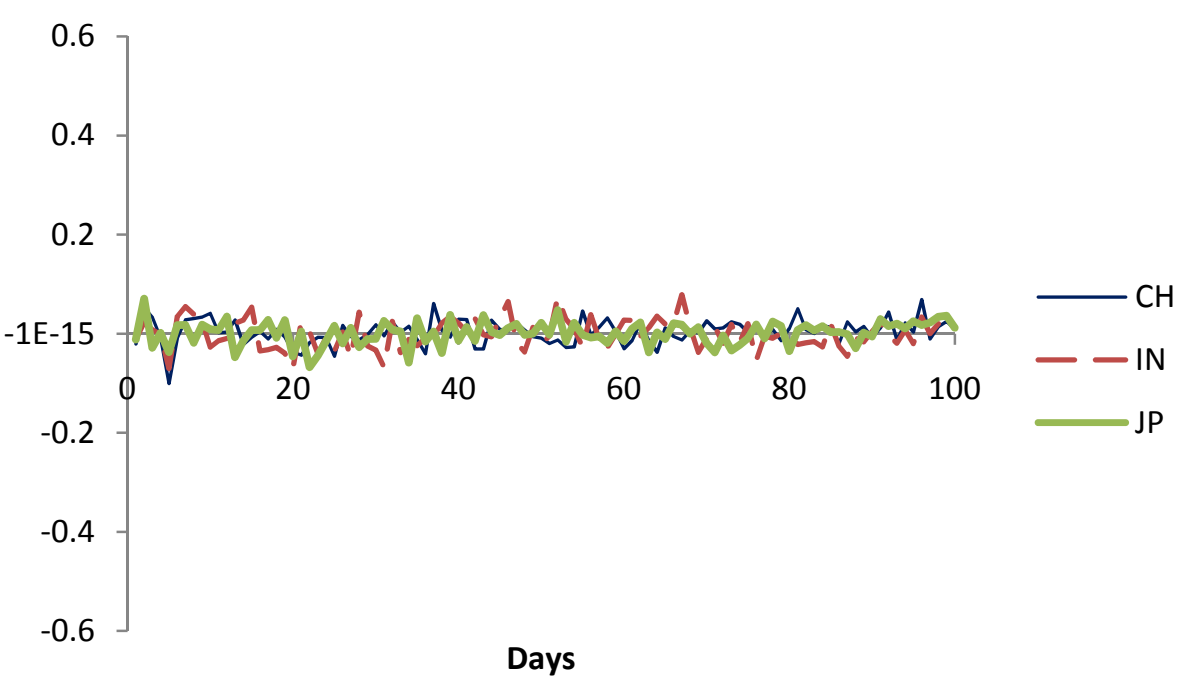

